\title{
Breast-feeding and Helicobacter pylori infection: systematic review and meta-analysis
}

\author{
Helena Carreira ${ }^{1,2, *}$, Ana Bastos ${ }^{1,2}$, Bárbara Peleteiro ${ }^{1,2}$ and Nuno Lunet $^{1,2}$ \\ 'Department of Clinical Epidemiology, Predictive Medicine and Public Health, University of Porto Medical School, \\ Al. Prof. Hernâni Monteiro, 4200-319, Porto, Portugal: ${ }^{2}$ Institute of Public Health of the University of Porto (ISPUP), \\ Porto, Portugal
}

Submitted 8 July 2013: Final revision received 12 February 2014: Accepted 26 February 2014: First published online 1 May 2014

\begin{abstract}
Objective: To quantify the association between breast-feeding and Helicobacter pylori infection, among children and adolescents.

Design: We searched MEDLINE ${ }^{\mathrm{TM}}$ and Scopus ${ }^{\mathrm{TM}}$ up to January 2013. Summary relative risk estimates (RR) and $95 \%$ confidence intervals were computed through the DerSimonian and Laird method. Heterogeneity was quantified using the $I^{2}$ statistic.

Setting: Twenty-seven countries/regions; four low-income, thirteen middleincome and ten high-income countries/regions.

Subjects: Studies involving samples of children and adolescents, aged 0 to 19 years.

Results: We identified thirty-eight eligible studies, which is nearly twice the number included in a previous meta-analysis on this topic. Fifteen studies compared ever $v$. never breast-fed subjects; the summary RR was 0.87 (95\% CI $\left.0.57,1.32 ; I^{2}=34.4 \%\right)$ in middle-income and 0.85 (95\% CI $\left.0.54,1.34 ; I^{2}=79.1 \%\right)$ in high-income settings. The effect of breast-feeding for $\geq 4-6$ months was assessed in ten studies from middle-income (summary RR $=0.66 ; 95 \%$ CI 0.44 , $0.98 ; I^{2}=65.7 \%$ ) and two from high-income countries (summary RR $=1.56 ; 95 \%$ CI $0.57,4 \cdot 26 ; I^{2}=68 \cdot 3 \%$ ). Two studies assessed the effect of exclusive breastfeeding until 6 months $(\mathrm{OR}=0.91 ; 95 \%$ CI 0.61, 1.34 and OR=1.71;95\% CI 0.66, $4 \cdot 47$, respectively).

Conclusions: Our results suggest a protective effect of breast-feeding in economically less developed settings. However, further research is needed, with a finer assessment of the exposure to breast-feeding and careful control for confounding, before definite conclusions can be reached.
\end{abstract}

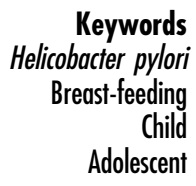

Helicobacter pylori infection has been classified a definite human carcinogen for almost two decades and is well accepted as the single most important risk factor for non-cardia gastric cancer ${ }^{(1,2)}$. Although the prevalence of infection has been decreasing in many of the more economically developed countries ${ }^{(3,4)}$, it was estimated to be responsible for nearly one-third of the 2 million cases of cancer occurring worldwide due to infections in $2008^{(5)}$.

H. pylori infection is acquired mainly during childhood and adolescence ${ }^{(6-8)}$; once obtained, and in the absence of a specific treatment, it can persist for decades ${ }^{(9)}$. Therefore, understanding the role of modifiable exposures that may be targeted to decrease the rate of $H$. pylori infection during childhood is of key importance to prevent its occurrence. Factors that promote interpersonal contact or are associated with poor hygienic conditions, including being born in a setting with a high prevalence of infection ${ }^{(10)}$, having parents with a low education level ${ }^{(11)}$, sharing a room with other subjects ${ }^{(12)}$ or attending a childcare institution $^{(13)}$, have been consistently associated with $H$. pylori infection in the early years of life. Breast-feeding has long been recognized as protective against gastrointestinal and respiratory diseases ${ }^{(14,15)}$, and a role in the infection with $H$. pylori may be postulated.

A previous systematic review including sixteen studies suggested a protective effect of breast-feeding in middle- and low-income countries ${ }^{(16)}$. However, the understanding of the relationship between breast-feeding 
and $H$. pylori infection may be improved by taking into account more detailed and accurate definitions of the exposure. Furthermore, a set of additional studies were published since the previous meta-analysis, allowing an update of the existing evidence on this topic.

Therefore, we conducted a new systematic review and meta-analysis to quantify the association between breastfeeding and H. pylori infection, among children and adolescents.

\section{Methods}

\section{Search strategy}

We searched MEDLINE ${ }^{\mathrm{TM}}$ and Scopus ${ }^{\mathrm{TM}}$ up to January 2013 to identify studies addressing the association between breast-feeding and $H$. pylori infection in childhood or adolescence. The PubMed ${ }^{\mathrm{TM}}$ and Scopus ${ }^{\mathrm{TM}}$ search expressions, and the systematic review flowchart, are presented in Fig. 1 according to the PRISMA (Preferred Reporting Items for Systematic Reviews and MetaAnalyses) Statement ${ }^{(17)}$. The literature search was further complemented by backward citation tracking among the articles considered eligible for the systematic review.

\section{Selection of the studies}

The studies were assessed independently by two researchers (H.C. and B.P. or H.C. and A.B.) in three consecutive steps to determine their eligibility; disagreements were discussed and resolved by consensus or involving a third researcher (N.L.).

In step 1, the studies were evaluated considering only the information presented in the title and abstract. When the abstract was not available, the study was further assessed, except when the title provided enough information to unequivocally exclude it. The full texts of the articles selected for step 2 were read to evaluate their eligibility and adequacy for data extraction; in step 3 the studies were re-evaluated to determine their eligibility for meta-analysis.

We excluded studies according to the following a priori defined criteria: (i) studies with full text not written in English, French, Italian, Polish, Portuguese or Spanish; (ii) reports not involving humans (e.g. in vitro studies); (iii) review articles, editorials, methodological studies, case reports or comments; (iv) studies in which the sample selection was dependent on the risk of $H$. pylori infection and therefore not expected to represent the general population (e.g. children undergoing endoscopy for diagnostic procedures); (v) studies not providing data on the association between breast-feeding and $H$. pylori infection; (vi) studies assessing the $H$. pylori infection status only in adults; and (vii) duplicate reports of the same study (data could be extracted from one or more of the multiple reports to obtain the most complete information).

\section{Data extraction}

The following data were extracted from the original reports: (i) year of publication; (ii) country and region where the study was conducted; (iii) study design; (iv) sample characteristics (sample size and age distribution); (v) methods used to determine the H. pylori infection status; (vi) exposure to breast-feeding, namely regarding its duration and exclusiveness; and (vii) relative risk (RR) estimates, namely risk ratios, incidence rate ratios or odds ratios, preferably adjusted for the larger number of potential confounders, or the necessary information to compute them, along with the corresponding precision estimates. Specific estimates for exclusive and nonexclusive breast-feeding or different durations of exposure were extracted whenever available.

For the studies providing data for age groups including adults in addition to children and/or adolescents (e.g. 10-29 years), we computed the mid-point year and excluded the data when it was higher than 18 years.

The discrepancies in the data extracted independently by two reviewers (H.C. and B.P. or H.C. and A.B.) were discussed and resolved by consensus, or involving a third researcher (N.L.).

\section{Meta-analysis}

The DerSimonian and Laird method was used to compute summary estimates of the association between breastfeeding and $H$. pylori infection, and respective $95 \%$ confidence intervals. Heterogeneity was quantified using the $I^{2}$ statistic $^{(18)}$.

Stratified analyses according to the characteristics of the populations and methodological specificities with potential impact on the internal or external validity of the results (economic development of the countries where the investigations were conducted $^{(19)}$, age of the participants, adjustment for the potential confounding effect of socio-economic status, method used to assess the H. pylori infection status, prevalence of $H$. pylori infection in the non-exposed participants, prevalence of breast-feeding) were conducted to identify factors associated with heterogeneous results.

Funnel plots and the Egger's regression asymmetry test were used for assessment of 'small studies effects' ${ }^{\text {,20) }}$. The statistical analysis was performed using the STATA ${ }^{\circledR}$ statistical software package version 9.2.

No review protocol was registered.

\section{Results}

We identified thirty-eight studies eligible for the systematic review $^{(7,10-12,21,30,32-55)}$ (Fig. 1 and Appendices 1 and 2). The studies involved samples of children and adolescents, aged 0 to 19 years, recruited in twenty-seven countries/ regions, including four low-income ${ }^{(21,40,41,46,47)}$, thirteen middle-income ${ }^{(22,24-28,30,32-34,37-39,42,44,49-53,55)}$ and ten high-income countries/regions ${ }^{(7,10-12,23,29,35,36,43,45,48,49,54)}$. 
1471 publications identified through PubMed ${ }^{\mathrm{TM}}(n 619)$ and $\mathrm{Scopus}^{\mathrm{TM}}(n$ 852) search

PubMed search expression: ((((Helicobacter pylori OR Campylobacter pylori) AND (breastfeeding OR 'breast-feeding' OR 'breast milk' OR nursing [tiab] OR (risk factors AND (child, preschool OR children)) OR (child care OR kindergarten OR nursery OR nursery school OR child day care centers OR 'day care centers' OR 'day care' OR 'group care')) NOT (animals NOT humans)))

Scopus search expression: TITLE-ABS-KEY ((Helicobacter pylori OR Campylobacter pylori) AND (breastfeeding OR 'breast-feeding' OR 'breast milk' OR nursing OR (risk factors AND children)))
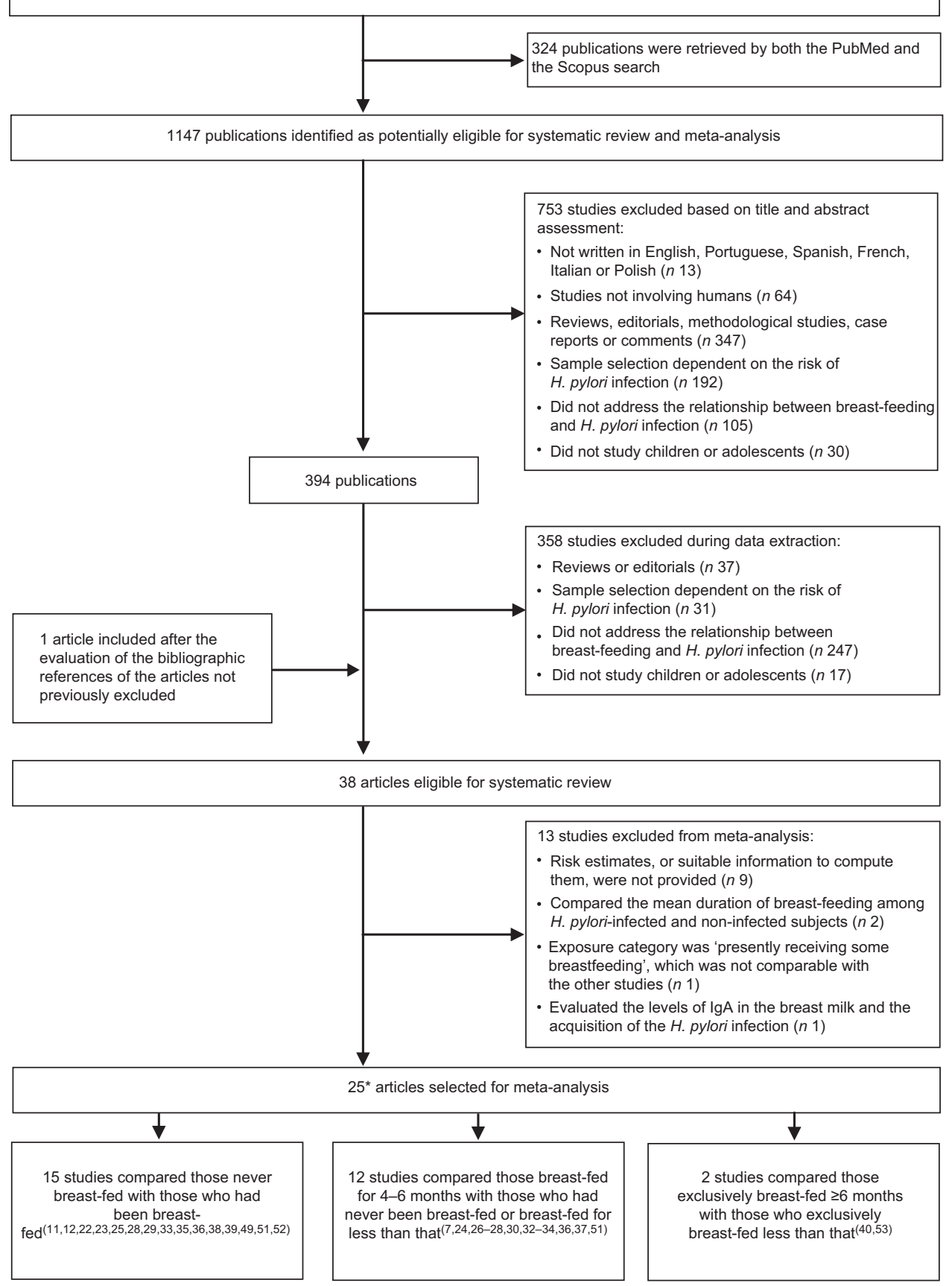

Fig. 1 Systematic review flowchart according to the PRISMA (Preferred Reporting Items for Systematic Reviews and MetaAnalyses) Statement ${ }^{(17)}$. ${ }^{*}$ Four studies ${ }^{(27,32,35,50)}$ provided data to quantify the association between both having been breast-fed and having been breast-fed for 4-6 months and Helicobacter pylori infection

Most studies had a cross-sectional design and eight were cohort studies $^{(37,39,40,44,45,47,49,53)}$.

Thirteen studies did not provide information to compute an RR estimate for the association between breast-feeding and H. pylori infection ${ }^{(10,21,41-48,50,54,55)}$ (Appendix 1). From these, eight referred a lack of association between breast-feeding and $H$. pylori infection, although the point estimates were not provided ${ }^{(10,41,43-45,47,50,54)}$. One study 
reported that the 'percentage of breastfeeding in the population in Korat was $61.25 \%$; the selected group of seropositive children had $51 \%$ of exclusive breastfeeding for more than 6 months and $21.5 \%$ the seropositive children had a history of breastfeeding for less than 6 months, ${ }^{(55)}$. One study involved a sample of children aged from 1 to 99 months and defined exposure as 'presently receiving some breastmilk' ${ }^{\text {(46) }}$, which is not comparable with the definitions of breast-feeding used in the remaining reports. Two studies compared the mean duration of breast-feeding among $H$. pylori-infected and non-infected subjects ${ }^{(42,48)}$, and therefore could not be considered for meta-analysis; only one study showed a shorter duration of breast-feeding among the participants who were infected. Thomas et al. ${ }^{(21)}$ compared the levels of IgA in the breast milk of the mothers and the infection with $H$. pylori in the respective children; the five children from the mothers who produced the lowest levels of IgA were infected.

Twenty-five studies ${ }^{(7,11,12,22-30,32-40,49,51-53)}$, from high-, middle- and low-income countries, provided data to quantify the association between breast-feeding and H. pylori. Among those, fifteen compared breast-fed $v$. non-breast-fed subjects $^{(11,12,22,23,25,28,29,33,35,36,38,39,49,51,52)}$ and twelve compared subjects breast-fed for 4-6 months $v$. never breast-fed or breast-fed for less than 4-6 months $^{(7,24,26-28,30,32-34,36,37,51)}$. Two studies specifically addressed the exclusive breast-feeding until the age of 6 months $^{(40,53)}$ (Appendix 2).

\section{H. pylori infection according to bistory of breast-feeding (ever v. never)}

Having been breast-fed was not significantly associated with $H$. pylori infection in either high-income (summary $\mathrm{RR}=0.85 ; 95 \%$ CI $\left.0.54,1.34 ; I^{2}=79.1 \%\right)$ or middleincome countries (summary RR $=0.87$; $95 \%$ CI 0.57, 1.32; $I^{2}=34.4 \%$ ). The results were heterogeneous, possibly reflecting a large inter-study variation in the duration of breast-feeding, since the prevalence of breast-feeding and the age range of the participants varied widely across studies (Fig. 2).

The visual inspection of the funnel plot did not suggest the occurrence of publication bias (Fig. 3). This is corroborated by the Egger's asymmetry test $(P=0 \cdot 84)$.

\section{H. pylori infection according to duration of breast-feeding}

Only two studies provided data to evaluate the association between being breast-fed for 4 months or more $v$. never breast-fed or breast-fed for less than 4-6 months in highincome settings ${ }^{(7,36)}$. The overall RR estimate was 1.56 (95\% CI $0.57,4.26 ; I^{2}=68.3 \%$; Fig. 4). The single study that provided an RR estimate adjusted for confounders yielded an OR of 2.57 (95\% CI 1.19, 5.55).

The combined results of the ten studies conducted in middle-income settings showed a summary RR of 0.66
(95\% CI $0.44,0.98 ; I^{2}=65.7 \%$ ). The summary RR was non-significant when considering the adjustment for potential confounding effect of socio-economic factors (adjusted: summary $\mathrm{RR}=0.77 ; \quad 95 \%$ CI $\quad 0.48, \quad 1.20$; $I^{2}=40 \cdot 5 \%$; unadjusted: summary RR $=0.58 ; 95 \%$ CI $0 \cdot 30$, $1 \cdot 10 ; I^{2}=76 \cdot 3 \%$ ), or the prevalence of $H$. pylori infection among the non-exposed subjects (using the median as cutoff; $\leq 43 \%$ : summary $\mathrm{RR}=0.67 ; 95 \%$ CI $0.35, \quad 1 \cdot 27$; $I^{2}=75 \cdot 0 \%$; $>43 \%$ : summary RR $=0 \cdot 66 ; 95 \%$ CI $0 \cdot 38,1 \cdot 15$; $\left.I^{2}=60.7 \%\right)$. The three studies that used diagnostic tests based on the detection of stool antigens yielded lower RR estimates (summary $\mathrm{RR}=0.33 ; \quad 95 \%$ CI $0.15, \quad 0.73$; $I^{2}=64.3 \%$ ), as did the seven studies with younger subjects (using the median as cut-off; $\leq 7$ years: summary $R R=0.50$; $95 \%$ CI $0.32, \quad 0.78 ; \quad I^{2}=56.7 \% ;>7$ years: summary $\mathrm{RR}=1.09 ; 95 \%$ CI $\left.0.77,1.55 ; I^{2}=0.0 \%\right)$. The only cohort analysis showed a non-significant positive association between breast-feeding and $H$. pylori infection $(\mathrm{RR}=2 \cdot 54$; $95 \%$ CI $0 \cdot 29,22 \cdot 40$ ), although only six out of 110 children seroconverted during the 2-year follow-up period since birth $^{(37)}$.

The visual inspection of the funnel plot and the results of the Egger's asymmetry test $(P=0.82)$ did not suggest publication bias (Fig. 3).

\section{H. pylori infection according to bistory of exclusive breast-feeding}

Two studies ${ }^{(40,53)}$, conducted in Ethiopia (low-income country) and in Chile (middle-income country), assessed the effect of exclusive breast-feeding for more than 6 months; the RR was 0.91 (95\% CI $0.61,1.34$ ) and 1.71 (95\% CI 0.66, 4.47) in the low- and middle-income setting, respectively.

\section{Discussion}

The available evidence on the relationship between breast-feeding and H. pylori infection is compatible with a protective effect in the less economically developed settings. However, only a few studies accounted for the potential confounding by socio-economic factors or assessed the effects of breast-feeding duration or exclusivity, precluding definite conclusions on this topic.

The present study updated a previous systematic review and meta-analysis conducted by Chak et al. ${ }^{(16)}$ and the interpretation of our findings needs to take into account the evidence that was published since then, as well as the differences in the completeness of the search strategy and options for data synthesis. The present systematic review included eighteen studies ${ }^{(7,22-26,29,30,32,34,37,38,50-55)}$ that were not considered in the paper published by Chak et $a l{ }^{(16)}$; most of the studies were published since then and two ${ }^{(25,37)}$ were written in languages probably not considered in the previous review. However, due to our methodological options, six studies ${ }^{(31,46,56-59)}$ included in 
$\operatorname{RR}(95 \% \mathrm{Cl})$

Country

SES
adjusted

Age
(years)

not BF

$0.54(0.28,1.05)$

Gold et al. (1997) ${ }^{(49)}$

Malaty et al. (2001) ${ }^{(11)}$

Dore et al. (2002) ${ }^{(35)}$ (rural area)

Dore et al. (2002) ${ }^{(35)}$ (urban area)

Rothenbacher et al. (2002) ${ }^{(36)}$

Rowland et al. (2006) ${ }^{(29)}$

Sykora et al. (2009) ${ }^{(23)}$

Subtotal $\left(R^{2}=79 \cdot 1 \%, P=0.0000\right)$

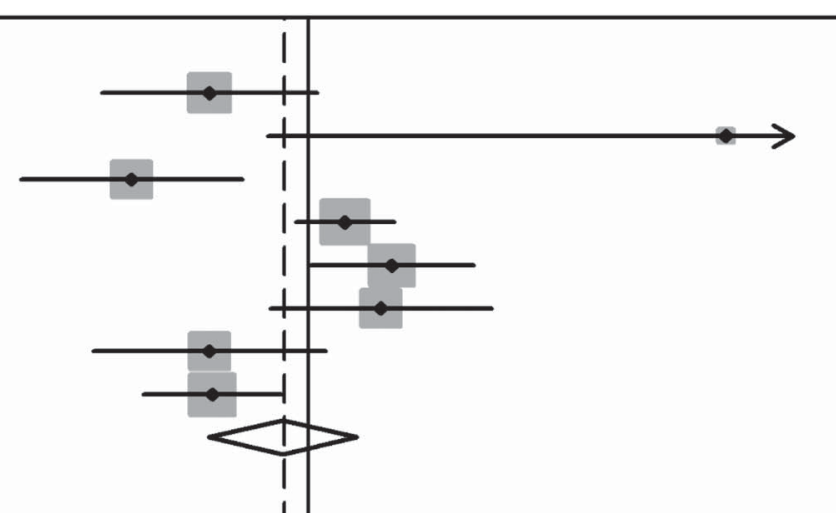

\section{Middle income}

Klein et al. (1991) ${ }^{(52)}$ Naficy et al. $(2000)^{(39)}$ Omar et al. $(2001)^{(38)}$ Ertem et al. (2003) $)^{(33)}$ Rodrigues et al. (2006) ${ }^{(28)}$ Rodrigues et al. (2007) ${ }^{(25)}$ Miranda et al. (2010) Jafar et al. $(2013)^{(51)}$

Subtotal $\left(R^{2}=34 \cdot 4 \%, P=0.154\right)$

Overall $\left(R^{2}=66 \cdot 1 \%, P=0.000\right)$

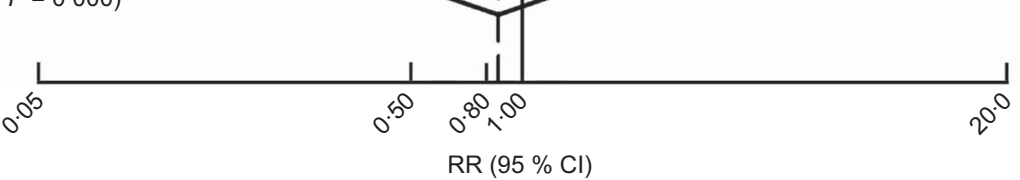

$13.20(0.78,224.45) \quad$ TWN

$0.33(0.17,0.66)$

$1.25(0.92,1.69)$

$1 \cdot 67(1 \cdot 01,2 \cdot 76)$

$1.56(0.79,3 \cdot 10)$

$0.54(0.26,1.11)$

$0.55(0.36 \cdot 0.84)$

$0.85(0.54,1.34)$

$1.25(0.62,2.52)$
$1.40(0.35,5.54)$
$0.48(0.18,1.29)$
$0.22(0.05,0.96)$
$0.89(0.31,2.56)$
$4.24(0.93,19.31)$
$0.83(0.53,1.30)$
$0.66(0.21,2.07)$
$0.87(0.57,1.32)$

$0.86(0.63,1.17)$

$\begin{array}{lccccc}\text { PER } & \text { No } & 0 \cdot 2-12 & 19 \cdot 6 & 65 \cdot 1 & \text { UBT } \\ \text { EGY } & \text { No } & 0 \cdot 5-2 \cdot 9 & 8 & \text { NA } & \text { SI } \\ \text { EGY } & \text { No } & 1 \cdot 5-16 & 65 & \text { NA } & \text { SI } \\ \text { TUR } & \text { Yes } & 3-12 & 72 \cdot 7 & 93 \cdot 0 & \text { UBT } \\ \text { BRA } & \text { Yes } & 0 \cdot 5-14 & 52 & 93 \cdot 2 & \text { UBT } \\ \text { BRA } & \text { No } & 2-13 & 13 \cdot 3 & 92 \cdot 5 & \text { SI } \\ \text { BRA } & \text { No } & 0-12+ & 37 \cdot 8 & 62 \cdot 2 & \text { SI } \\ \text { IRN } & \text { No } & 0 \cdot 3-15 & 76 & 95 \cdot 5 & \text { SA }\end{array}$

Fig. 2 Meta-analyses of studies evaluating the association between ever being breast-fed and Helicobacter pylori infection. Relative risk (RR) estimates and 95\% confidence intervals of $H$. pylori infection according to economic development of the countries where the investigations were conducted ${ }^{(19)}$. For each study, the black diamond indicates the best estimate, the size of the grey square indicates the study's weight in the analysis (weights are from random-effects analysis) and the horizontal line represents the $95 \% \mathrm{Cl}$. The centre of the open diamond indicates the summary estimate of the RR and its width represents the $95 \% \mathrm{Cl}$ of the summary RR estimate. General abbreviations: SES, socio-economic status; Prev., prevalence (\%); HP +, H. pylori-infected; BF, breast-feeding; NA, not available. Abbreviations for countries: BRA, Brazil; TWN, Taiwan, Republic of China; CZE, Czech Republic; DEU, Germany; EGY, Egypt; GBR, United Kingdom; IRL, Ireland; IRN, Islamic Republic of Iran; ITA, Italy; PER, Peru; TUR, Turkey. Abbreviations for tests: SA, test based country. However, for most indicators, Taiwan's data are not added to the data for China, but it is added to the world aggregate and the high-income countries aggregate. Therefore, Taiwan was included along with other high-income settings 

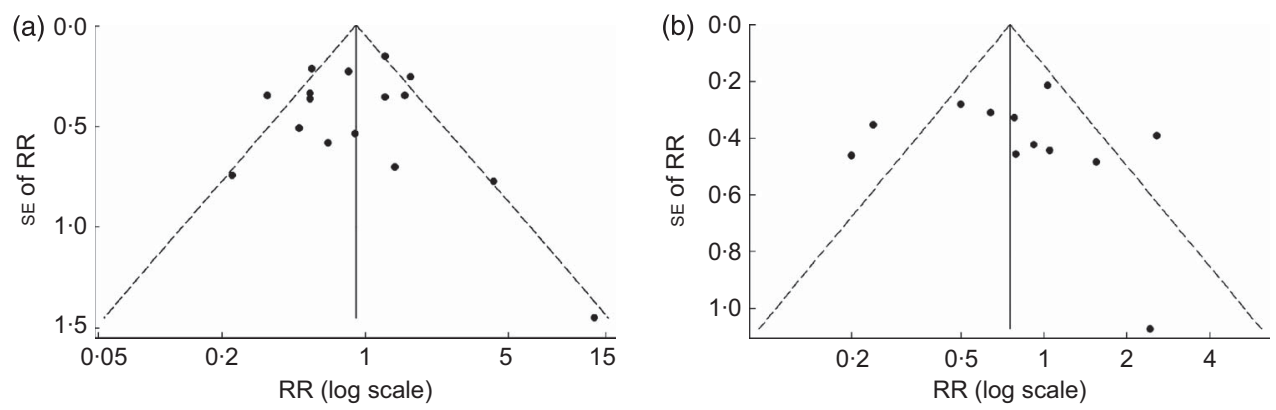

Fig. 3 Funnel plot of studies evaluating the association between breast-feeding and Helicobacter pylori infection: (a) ever breastfeeding $v$. never; (b) breast-feeding for 4-6 months $v$. less than that. Studies were plotted with their relative risk (RR) estimate on the $x$-axis (log scale) and the corresponding standard error of the RR along the $y$-axis; pseudo $95 \%$ confidence limits are represented by dashed lines

the previous meta-analysis were not included in our meta-analyses. The study by Suoglu et al. ${ }^{(58)}$ was not eligible because the sample selection was not independent of the H. pylori status. The study by Braga et al. ${ }^{(59)}$ included a sample that partially overlapped with the sample of the study by Rodrigues et $a l .{ }^{(28)}$ and only the latter was considered in our review. The study by Mahalanabis et al. ${ }^{(46)}$ defined the exposure as 'presently receiving some breast milk' although it also included children old enough for not being breast-fed for a long time and was therefore excluded from our analyses. We also opted for not including the studies evaluating the $H$. pylori infection status in adulthood ${ }^{(31,56,57)}$, as the larger the lag between the exposure to breast-feeding and the assessment of infection status, the more likely it is that the RR estimates reflect the effect of other factors in addition to breast-feeding, namely taking into account that the incidence rates may remain high throughout adolescence ${ }^{(60)}$.

The inclusion of a larger number of studies allowed a finer assessment of the exposure of breast-feeding. Chak et al. $^{(16)}$ provided a summary OR estimate combining the results of all eligible studies, regardless of the breast-feeding definition, and conducted stratified analysis according to the duration of breast-feeding ( $\geq 4$ months $v$. $<4$ months or not specified). We opted for conducting two sets of analyses: (i) according to the breast-feeding status (ever breast-fed $v$. never breast-fed); and (ii) according to the duration of breast-feeding ( $\geq 4-6$ months $v$. $<4-6$ months). Despite our efforts to combine the results from more homogeneous groups of studies, the inter-study variability in the estimates remained high. Among the studies that assessed the $H$. pylori status among those ever breast-fed and those who were never, the heterogeneity of the results is likely to be explained primarily by the differences implicit in the definition of ever having been breast-fed, which may include children breast-fed for one week or one year; however, the original reports did not provide information to account for these methodological aspects in our analyses. This depicts the need for standardized breast-feeding definitions to be used for the collection and description of data on this topic ${ }^{(61)}$. In 1988, the Interagency Group for Action on Breastfeeding ${ }^{(62)}$ recognized that the term 'breast-feeding' is not enough to accurately describe its numerous variations. Specifically, it is required to distinguish between full and partial breast-feeding, and between the different levels of partial breast-feeding $^{(62)}$.

Our results suggest that having been breast-fed for 4-6 months is associated with a lower risk of $H$. pylori infection only in middle-income countries. We may hypothesize that in the latter settings children who are being breast-fed may present a substantially better nutritional status and therefore present more resistance to infections. Also, children whose mothers had breast milk with higher levels of anti-H. pylori IgA had a lower risk of H. pylori infection, compared with those whose mothers had lower levels ${ }^{(21)}$. Furthermore, breast-feeding may protect against the acquisition of the infection by acting as a natural antibiotic, as bovine lactoferrin was shown to inhibit the growth of $H$. pylori ${ }^{(63-65)}$; lactoferrin is much more abundant in breast milk than it is in cow's milk. Another component of breast milk, $\kappa$-casein, was shown to play a role in the inhibition of $H$. pylori adhesion to gastric mucosa ${ }^{(66)}$.

Although similar results were obtained when considering crude RR estimates with those adjusted for the potential confounding by socio-economic factors, this is a methodological aspect of major importance and a sound assessment of this relationship requires the control of these confounders. The relationship between low socio-economic status and H. pylori infection is well known ${ }^{(67,68)}$. Breast-feeding is also influenced by these factors, although the relationship may vary with time and across settings with different economic and cultural background ${ }^{(69-71)}$.

There was no association between breast-feeding and $H$. pylori infection when only the studies including older children were considered for analysis, which may reflect a lack of longer-term effects of breast-feeding, or that more important risk factors exert their effects after the cessation of breast-feeding. 


\section{High income}

Rothenbacher et al. (2002) ${ }^{(36)}$

Muhsen et al. (2012) $)^{(7)}$

Subtotal $\left(R^{2}=68.3 \%, P=0.076\right)$

\section{Middle income}

Belkind-Gerson et al. (2001) ${ }^{(37)}$

Ertem et al. (2003) ${ }^{(33)}$

Moraes \& da Silva $(2003)^{(32)}$

Ndip et al. $(2004)^{(30) *}$

Ito et al. (2006) ${ }^{(26)}$

Rodrigues et al. (2006) $)^{(28)}$

Nguyen et al. (2006) ${ }^{(27)}$

Yucel et al. (2009) ${ }^{(24)}$

Ozen et al. (2011) $)^{(34)}$

Jafar et al. $(2013)^{(51)}$

Subtotal $\left(I^{2}=65 \cdot 7 \%, P=0.002\right)$

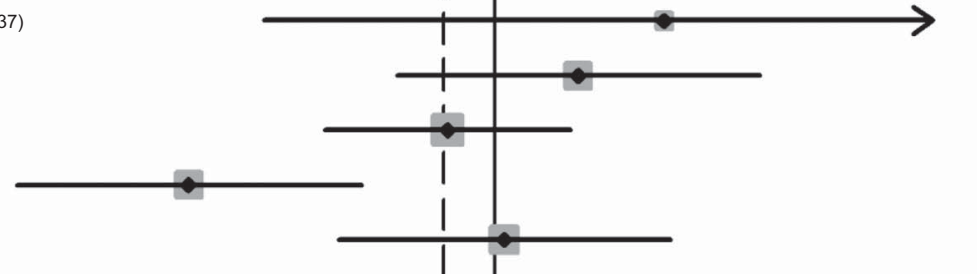

$2.43(0.30,19.89) \quad M$

$1.55(0.60,4 \cdot 01)$

$0.78(0.41,1.49)$

$0.20(0.08,0.49)$

$1.05(0.44,2.51)$

$0.64(0.35,1 \cdot 18)$

$0.50(0.29,0.87)$

$0.24(0.12,0.48)$

$1.03(0.68,1.57)$

$0.79(0.32,1.94)$

$0.66(0.44,0.98)$

MEX No

\section{No}

0-2

$2 \cdot 9$

NA UBT

TUR Yes 3-12

$45 \cdot 9$

93 UBT

BRA

No 2-10

$50 \cdot 0$

$81.6 \mathrm{SI}$

CMR No 0-10

$44 \cdot 1$

NA SA

BRA Yes 0-19

$33 \cdot 1$

NA SI

BRA

Yes $\quad 0.5-14$

57

93.2 UBT

VNM Yes 0.5-15

$37 \cdot 4$

NA SI

TUR

No 2-12

41.9

93.9 SA

TUR

No $\quad 6-15$

$33 \cdot 1$

NA

SI

IRN

0.3-15

$73 \cdot 1$

95.5

$0.76(0.51,1 \cdot 13)$

Overall $\left(I^{2}=70 \cdot 4 \%, P=0.000\right)$

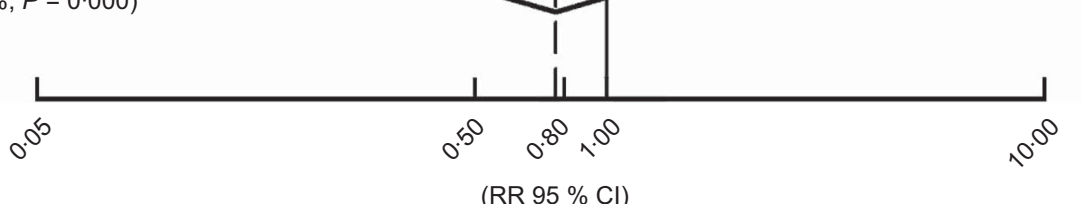

(RR $95 \% \mathrm{Cl}$ )

Fig. 4 Meta-analyses of studies evaluating the association between the duration of breast-feeding ( $<4-6$ months $v$. $>4-6$ months) and Helicobacter pylori infection. Relative risk (RR) estimates and $95 \%$ confidence intervals of $H$. pylori infection according to economic development of the countries where the investigations were conducted ${ }^{(19)}$. For each study, the black diamond indicates the best estimate, the size of the grey square indicates the study's weight in the analysis (weights are from random-effects analysis) and the horizontal line represents the $95 \% \mathrm{Cl}$. The centre of the open diamond indicates the summary estimate of the RR and its width represents the $95 \% \mathrm{Cl}$ of the summary RR estimate. General abbreviations: SES, socio-economic status; Prev., prevalence (\%); HP +, H. pylori-infected; BF, breast-feeding; NA, not available. Abbreviations for countries: BRA, Brazil; CMR, Cameroon; DEU, Germany; IRN, Islamic Republic of Iran; IRS, Israel; MEX, Mexico; TUR, Turkey; VNM, Vietnam. Abbreviations for tests: SA, test based on the detection of stool antigens; SI, test based on serum immunology; UBT, urea breath test. *Study comparing those who were breast-fed for more than 6 months with those breast-fed for less than 2 months. A sensitivity analysis excluding this study yielded an overall RR estimate of $0.80\left(95 \% \mathrm{Cl} 0.54,1.19 ; I^{2}=65.8 \%\right)$ 


\section{Conclusion}

In conclusion, our results suggest a protective effect of breast-feeding in economically less developed settings. However, further research is needed, with a finer assessment of the exposure to breast-feeding and infection status, as well as a careful control of confounding, before definite conclusions can be reached.

\section{Acknowledgements}

Financial support: This study was funded by a grant of the Fundação para a Ciência e a Tecnologia (grant number PTDC/SAU-EPI/122460/2010). The Fundação para a Ciência e a Tecnologia had no role in the design, analysis or writing of the article. Conflict of interest: None. Authorship: H.C. conceived the study and performed the collection and analyses of data under the supervision of N.L. at all stages of its implementation. A.B. and B.P. collaborated in data collection. All authors contributed to the interpretation of results and review of drafts of the manuscript, and read and approved the final submission of the manuscript.

\section{References}

1. Helicobacter and Cancer Collaborative Group (2001) Gastric cancer and Helicobacter pylori: a combined analysis of 12 case control studies nested within prospective cohorts. Gut 49, 347-353.

2. International Agency for Research on Cancer \& World Health Organization (2009) A Review of Human Carcinogens. Part B: Biological Agents/IARC Working Group on the Evaluation of Carcinogenic Risks to Humans. Lyon: IARC.

3. Asfeldt AM, Straume B, Steigen SE et al. (2008) Changes in the prevalence of dyspepsia and Helicobacter pylori infection after 17 years: the Sorreisa gastrointestinal disorder study. Eur J Epidemiol 23, 625-633.

4. Gause-Nilsson I, Gnarpe H, Gnarpe J et al. (1998) Helicobacter pylori serology in elderly people: a 21-year cohort comparison in 70-year-olds and a 20-year longitudinal population study in 70-90-year-olds. Age Ageing 27, 433-436.

5. de Martel C, Ferlay J, Franceschi S et al. (2012) Global burden of cancers attributable to infections in 2008: a review and synthetic analysis. Lancet Oncol 13, 607-615.

6. Koch A, Krause TG, Krogfelt K et al. (2005) Seroprevalence and risk factors for Helicobacter pylori infection in Greenlanders. Helicobacter 10, 433-442.

7. Muhsen K, Jurban M, Goren S et al. (2012) Incidence, age of acquisition and risk factors of Helicobacter pylori infection among Israeli Arab infants. J Trop Pediatr 58, 208-213.

8. Oleastro M, Pelerito A, Nogueira P et al. (2011) Prevalence and incidence of Helicobacter pylori infection in a healthy pediatric population in the Lisbon area. Helicobacter 16, 363-372.

9. Sherman PM (2004) Appropriate strategies for testing and treating Helicobacter pylori in children: when and how? Am J Med 117, Suppl. 5A, 30S-35S.

10. Kivi M, Johansson AL, Reilly M et al. (2005) Helicobacter pylori status in family members as risk factors for infection in children. Epidemiol Infect 133, 645-652.

11. Malaty HM, Logan ND, Graham DY et al. (2001) Helicobacter pylori infection in preschool and school-aged minority children: effect of socioeconomic indicators and breastfeeding practices. Clin Infect Dis 32, 1387-1392.
12. McCallion WA, Murray LJ, Bailie AG et al. (1996) Helicobacter pylori infection in children: relation with current household living conditions. Gut 39, 18-21.

13. Bastos J, Carreira H, La Vecchia C et al. (2013) Childcare attendance and Helicobacter pylori infection: systematic review and meta-analysis. Eur J Cancer Prev 22, 311-319.

14. Quigley MA, Kelly YJ \& Sacker A (2007) Breastfeeding and hospitalization for diarrheal and respiratory infection in the United Kingdom Millennium Cohort Study. Pediatrics 119, e837-e842.

15. Wright AL, Bauer M, Naylor A et al. (1998) Increasing breastfeeding rates to reduce infant illness at the community level. Pediatrics 101, 837-844.

16. Chak E, Rutherford GW \& Steinmaus C (2009) The role of breast-feeding in the prevention of Helicobacter pylori infection: a systematic review. Clin Infect Dis $\mathbf{4 8}$, 430-437.

17. Moher D, Liberati A, Tetzlaff J et al. (2010) Preferred reporting items for systematic reviews and meta-analyses: the PRISMA statement. Int J Surg 8, 336-341.

18. Higgins JP \& Thompson SG (2002) Quantifying heterogeneity in a meta-analysis. Stat Med 21, 1539-1558.

19. The World Bank (2012) The World Bank Database Countries and Economies. http://data.worldbank.org/ country (accessed November 2012).

20. Sterne JA, Gavaghan D \& Egger M (2000) Publication and related bias in meta-analysis: power of statistical tests and prevalence in the literature. J Clin Epidemiol 53, 1119-1129.

21. Thomas JE, Austin S, Dale A et al. (1993) Protection by human milk IgA against Helicobacter pylori infection in infancy. Lancet 342, 121.

22. Miranda AC, Machado RS, Silva EM et al. (2010) Seroprevalence of Helicobacter pylori infection among children of low socioeconomic level in Sao Paulo. Sao Paulo Med J 128, $187-191$.

23. Sýkora J, Siala K, Varvarovska J et al. (2009) Epidemiology of Helicobacter pylori infection in asymptomatic children: a prospective population-based study from the Czech Republic. Application of a monoclonal-based antigen-instool enzyme immunoassay. Helicobacter 14, 286-297.

24. Yucel O, Sayan A \& Yildiz M (2009) The factors associated with asymptomatic carriage of Helicobacter pylori in children and their mothers living in three socio-economic settings. Jpn J Infect Dis 62, 120-124.

25. Rodrigues RV, Corvelo TC \& Ferrer MT (2007) Seroprevalence of Helicobacter pylori infection among children of different socioeconomic levels in Porto Velho, State of Rondonia. Rev Soc Bras Med Trop 40, 550-554.

26. Ito LS, Oba-Shinjo SM, Shinjo SK et al. (2006) Communitybased familial study of Helicobacter pylori infection among healthy Japanese Brazilians. Gastric Cancer 9, 208-216.

27. Nguyen BV, Nguyen KG, Phung CD et al. (2006) Prevalence of and factors associated with Helicobacter pylori infection in children in the north of Vietnam. Am J Trop Med Hyg 74, 536-539.

28. Rodrigues MN, Queiroz DM, Braga AB et al. (2006) History of breastfeeding and Helicobacter pylori infection in children: results of a community-based study from northeastern Brazil. Trans $R$ Soc Trop Med Hyg 100, 470-475.

29. Rowland M, Daly L, Vaughan M et al. (2006) Age-specific incidence of Helicobacter pylori. Gastroenterology 130, 65-72.

30. Ndip RN, Malange AE, Akoachere JF et al. (2004) Helicobacter pylori antigens in the faeces of asymptomatic children in the Buea and Limbe health districts of Cameroon: a pilot study. Trop Med Int Health 9, 1036-1040.

31. Ueda M, Kikuchi S, Kasugai T et al. (2003) Helicobacter pylori risk associated with childhood home environment. Cancer Sci 94, 914-918.

32. Moraes MM \& da Silva GA (2003) Risk factors for Helicobacter pylori infection in children. J Pediatr (Rio J) 79, 21-28. 
33. Ertem D, Harmanci H \& Pehlivanoglu E (2003) Helicobacter pylori infection in Turkish preschool and school children: role of socioeconomic factors and breast feeding. Turk J Pediatr 45, 114-122.

34. Ozen A, Furman A, Berber M et al. (2011) The effect of Helicobacter pylori and economic status on growth parameters and leptin, ghrelin, and insulin-like growth factor (IGF)-I concentrations in children. Helicobacter 16, $55-65$.

35. Dore MP, Malaty HM, Graham DY et al. (2002) Risk factors associated with Helicobacter pylori infection among children in a defined geographic area. Clin Infect Dis 35, 240-245.

36. Rothenbacher D, Bode G \& Brenner H (2002) History of breastfeeding and Helicobacter pylori infection in preschool children: results of a population-based study from Germany. Int J Epidemiol 31, 632-637.

37. Belkind-Gerson J, Basurto G, Newton O et al. (2001) Incidence of Helicobacter pylori infection in a cohort of infants in the State of Morelos. Salud Publica Mex 43, 122-126.

38. Omar AA, Ibrahim NK, Sarkis NN et al. (2001) Prevalence and possible risk factors of Helicobacter pylori infection among children attending Damanhour Teaching Hospital. J Egypt Public Health Assoc 76, 393-410.

39. Naficy AB, Frenck RW, Abu-Elyazeed R et al. (2000) Seroepidemiology of Helicobacter pylori infection in a population of Egyptian children. Int J Epidemiol 29, 928-932.

40. Lindkvist P, Enquselassie F, Asrat D et al. (1999) Helicobacter pylori infection in Ethiopian children: a cohort study. ScandJ Infect Dis 31, 475-480.

41. Hestvik E, Tylleskar T, Kaddu-Mulindwa DH et al. (2010) Helicobacter pylori in apparently healthy children aged 0-12 years in urban Kampala, Uganda: a community-based cross sectional survey. BMC Gastroenterol 10, 62.

42. Siai K, Ghozzi M, Ezzine H et al. (2008) Prevalence and risk factors of Helicobacter pylori infection in Tunisian children: 1055 children in Cap-Bon (northeastern Tunisia). Gastroenterol Clin Biol 32, 881-886.

43. Przybyszewska K, Bielanski W \& Fyderek K (2006) Frequency of Helicobacter pylori infection in children under 4 years of age. J Physiol Pharmacol 57, Suppl. 3, 113-122.

44. Glynn MK, Friedman CR, Gold BD et al. (2002) Seroincidence of Helicobacter pylori infection in a cohort of rural Bolivian children: acquisition and analysis of possible risk factors. Clin Infect Dis 35, 1059-1065.

45. Tindberg Y, Blennow M \& Granstrom M (1999) Clinical symptoms and social factors in a cohort of children spontaneously clearing Helicobacter pylori infection. Acta Paediatr 88, 631-635.

46. Mahalanabis D, Rahman MM, Sarker SA et al. (1996) Helicobacter pylori infection in the young in Bangladesh: prevalence, socioeconomic and nutritional aspects. Int $J$ Epidemiol 25, 894-898.

47. Bhuiyan TR, Qadri F, Saha A et al. (2009) Infection by Helicobacter pylori in Bangladeshi children from birth to two years: relation to blood group, nutritional status, and seasonality. Pediatr Infect Dis J 28, 79-85.

48. Okuda M, Miyashiro E, Koike M et al. (2001) Breast-feeding prevents Helicobacter pylori infection in early childhood. Pediatr Int 43, 714-715.

49. Gold BD, Khanna B, Huang LM et al. (1997) Helicobacter pylori acquisition in infancy after decline of maternal passive immunity. Pediatr Res 41, 641-646.

50. Daugule I, Rumba I, Lindkvist P et al. (2001) A relatively low prevalence of Helicobacter pylori infection in a healthy paediatric population in Riga, Latvia: a cross-sectional study. Acta Paediatr 90, 1199-1201.

51. Jafar S, Jalil A, Soheila N et al. (2013) Prevalence of Helicobacter pylori infection in children, a population-based cross-sectional study in west Iran. Iran J Pediatr 23, 13-18.
52. Klein PD, Graham DY, Gaillour A et al. (1991) Water source as risk factor for Helicobacter pylori infection in Peruvian children. Gastrointestinal Physiology Working Group. Lancet 337, 1503-1506.

53. O'Ryan ML, Rabello M, Cortes H et al. (2013) Dynamics of Helicobacter pylori detection in stools during the first 5 years of life in Chile, a rapidly developing country. Pediatr Infect Dis J 32, 99-103.

54. Rothenbacher D, Inceoglu J, Bode G et al. (2000) Acquisition of Helicobacter pylori infection in a high-risk population occurs within the first 2 years of life. J Pediatr 136, 744-748.

55. Vivatvakin B, Theamboonlers A, Semakachorn N et al. (2004) Prevalence of CagA and VacA genotype of Helicobacter pylori in Thai children. J Med Assoc Thai 87, 1327-1331.

56. Pearce MS, Thomas JE, Campbell DI et al. (2005) Does increased duration of exclusive breastfeeding protect against Helicobacter pylori infection? The Newcastle Thousand Families Cohort Study at age 49-51 years. J Pediatr Gastroenterol Nutr 41, 617-620.

57. Fall CH, Goggin PM, Hawtin P et al. (1997) Growth in infancy, infant feeding, childhood living conditions, and Helicobacter pylori infection at age 70. Arch Dis Child 77, 310-314.

58. Suoglu OD, Gokce S, Saglam AT et al. (2007) Association of Helicobacter pylori infection with gastroduodenal disease, epidemiologic factors and iron-deficiency anemia in Turkish children undergoing endoscopy, and impact on growth. Pediatr Int 49, 858-863.

59. Braga AB, Fialho AM, Rodrigues $\mathrm{MN}$ et al. (2007) Helicobacter pylori colonization among children up to 6 years: results of a community-based study from Northeastern Brazil. J Trop Pediatr 53, 393-397.

60. Bastos J, Peleteiro B, Pinto H et al. (2013) Prevalence, incidence and risk factors for Helicobacter pylori infection in a cohort of Portuguese adolescents (EpiTeen). Dig Liver Dis $\mathbf{4 5}$, 290-295.

61. Labbok MH \& Starling A (2012) Definitions of breastfeeding: call for the development and use of consistent definitions in research and peer-reviewed literature. Breastfeed Med $\mathbf{7}$, 397-402.

62. Labbok M \& Krasovec K (1990) Toward consistency in breastfeeding definitions. Stud Fam Plann 21, 226-230.

63. Dial EJ, Hall LR, Serna H et al. (1998) Antibiotic properties of bovine lactoferrin on Helicobacter pylori. Dig Dis Sci $\mathbf{4 3}$, $2750-2756$.

64. Wang X, Hirmo S, Willen R et al. (2001) Inhibition of Helicobacter pylori infection by bovine milk glycoconjugates in a BAlb/cA mouse model. J Med Microbiol 50, 430-435.

65. Dial EJ \& Lichtenberger LM (2002) Effect of lactoferrin on Helicobacter felis induced gastritis. Biochem Cell Biol 80, 113-117.

66. Hamosh M (1998) Protective function of proteins and lipids in human milk. Biol Neonate 74, 163-176.

67. Ford AC \& Axon AT (2010) Epidemiology of Helicobacter pylori infection and public health implications. Helicobacter 15, Suppl. 1, 1-6.

68. Graham DY, Malaty HM, Evans DG et al. (1991) Epidemiology of Helicobacter pylori in an asymptomatic population in the United States. Effect of age, race, and socioeconomic status. Gastroenterology 100, 1495-501.

69. Imdad A, Yakoob MY \& Bhutta ZA (2011) Effect of breastfeeding promotion interventions on breastfeeding rates, with special focus on developing countries. BMC Public Health 11, Suppl. 3, S24.

70. Inoue M, Binns CW, Otsuka K et al. (2012) Infant feeding practices and breastfeeding duration in Japan: a review. Int Breastfeed J 7, 15.

71. Lunet N \& Barros H (2012) Helicobacter pylori infection and gastric cancer: facing the enigmas. Int J Cancer 106, 953-960. 
Appendix 1 Main characteristics and results of the studies included in the systematic review but excluded from the meta-analysis

\begin{tabular}{|c|c|c|c|c|c|c|c|}
\hline \multirow{2}{*}{$\begin{array}{l}\text { Authors, year of } \\
\text { publication, } \\
\text { reference }\end{array}$} & \multirow[b]{2}{*}{ Country, region } & \multirow[b]{2}{*}{ Study population } & \multirow{2}{*}{$\begin{array}{l}\text { Age (years): range; } \\
\text { mean (SD) }\end{array}$} & \multicolumn{2}{|c|}{$\begin{array}{c}\text { Assessment of Helicobacter } \\
\text { pylori status }\end{array}$} & \multirow[b]{2}{*}{ Description of the main findings } & \multirow[b]{2}{*}{ Reason for exclusion } \\
\hline & & & & Sample & Method & & \\
\hline $\begin{array}{l}\text { Hestvik et al. } \\
\qquad(2010)^{(41)}\end{array}$ & $\begin{array}{l}\text { Uganda, } \\
\text { Kampala }\end{array}$ & $\begin{array}{l}\text { 'In the Mulago II parish } \\
\text { children aged 0-12 } \\
\text { years were recruited } \\
\text { consecutively by door- } \\
\text { to-door visits, an equal } \\
\text { number of children in } \\
\text { each age category [...]' }\end{array}$ & $\begin{array}{l}0-12 \\
4.8(3 \cdot 6)\end{array}$ & Stool & Immunoassay & $\begin{array}{l}\text { 'There were no significant } \\
\text { differences in prevalence by } \\
\text { breastfeeding duration (shorter } \\
\text { or longer than } 24 \text { weeks) [...]' }\end{array}$ & $\begin{array}{l}\text { An RR or suitable } \\
\text { information to compute it } \\
\text { was not provided }\end{array}$ \\
\hline $\begin{array}{l}\text { Bhuiyan et al. } \\
\qquad(2009)^{(47)}\end{array}$ & $\begin{array}{l}\text { Bangladesh, } \\
\text { Mirpur }\end{array}$ & $\begin{array}{l}\text { '695 pregnant mothers } \\
\text { were screened and } 321 \\
\text { newborn children were } \\
\text { enrolled. From this } \\
\text { cohort, } 238 \text { children } \\
\text { [...] who had } \\
\text { completed follow-up } \\
\text { and from whom } \\
\text { complete set of serum } \\
\text { and stool specimens } \\
\text { were available' }\end{array}$ & $\begin{array}{l}\text { Baseline: newborns } \\
\text { Follow-up: } 2 \text { years }\end{array}$ & $\begin{array}{l}\text { Blood } \\
\text { Stool }\end{array}$ & ELISA & $\begin{array}{l}\text { 'There was no difference in the } \\
\text { prevalence of } H \text {. pylori infection } \\
\text { among children who were } \\
\text { exclusively breast-fed in } \\
\text { comparison with those who } \\
\text { received mixed feedings when } \\
\text { analyzing samples collected } \\
\text { during the first } 6 \text { months of life } \\
(P=N S) \text { (data not shown). } \\
\text { Similarly, we could not find any } \\
\text { relationship between } H \text {. pylori } \\
\text { infection in children breast-fed } \\
\text { after age } 6 \text { months and those } \\
\text { who were not' }\end{array}$ & $\begin{array}{l}\text { An RR or suitable } \\
\text { information to compute it } \\
\text { was not provided }\end{array}$ \\
\hline Siai et al. $(2008)^{(42)}$ & Tunisia, Cap-Bon & $\begin{array}{l}\text { 'Among the } 10,703 \text { first- } \\
\text { grade pupils identified } \\
\text { in the healthcare } \\
\text { centers' databases, } \\
1055 \text { were randomly } \\
\text { selected for inclusion } \\
\text { (the first, 10th and } 20 \text { th } \\
\text { children on the health- } \\
\text { center lists)' }\end{array}$ & $\begin{array}{l}6-7 ; \\
\text { ND (ND) }\end{array}$ & Blood & ELISA (IgG) & $\begin{array}{l}\text { 'Statistically, there was no } \\
\text { difference between infected and } \\
\text { non infected children in terms of } \\
\text { the following variables: }[\ldots] \\
\text { duration of breastfeeding [...]. } \\
\text { Mean duration of breastfeeding: } \\
12.48 \text { months among } H \text {. pylori } \\
\text { positive subjects; } 11.85 \text { months } \\
\text { among } H \text {. pylori negative } \\
\text { subjects' }\end{array}$ & $\begin{array}{l}\text { It compares the mean } \\
\text { duration of breast- } \\
\text { feeding among } H \text {. pylori- } \\
\text { infected and non-infected } \\
\text { subjects }\end{array}$ \\
\hline $\begin{array}{l}\text { Przybyszewska } \\
\text { et al. }(2006)^{(43)}\end{array}$ & Poland, Cracow & $\begin{array}{l}\text { 'From } 1999 \text { until } 2001 \text { the } \\
\text { study was carried out } \\
\text { on randomly selected } \\
\text { healthy children aged } 6 \\
\text { months to } 4 \text { years, } \\
\text { attending Healthy Child } \\
\text { Centres in Cracovia for } \\
\text { their immunization or } \\
\text { physical assessment of } \\
\text { their health' }\end{array}$ & $\begin{array}{l}0.5-4.3 \\
2.7(0.98)\end{array}$ & Expired air & UBT & $\begin{array}{l}\text { 'Also } \mathrm{Hp} \text { infection was not } \\
\text { dependent on }[\ldots] \text { breastfeeding } \\
{[\ldots] \text { '... }}\end{array}$ & $\begin{array}{l}\text { An RR or suitable } \\
\text { information to compute it } \\
\text { was not provided }\end{array}$ \\
\hline
\end{tabular}


Appendix 1 Continued

\begin{tabular}{|c|c|c|c|c|c|c|c|}
\hline \multirow{2}{*}{$\begin{array}{l}\text { Authors, year of } \\
\text { publication, } \\
\text { reference }\end{array}$} & \multirow[b]{2}{*}{ Country, region } & \multirow[b]{2}{*}{ Study population } & \multirow{2}{*}{$\begin{array}{l}\text { Age (years): range; } \\
\text { mean (SD) }\end{array}$} & \multicolumn{2}{|c|}{$\begin{array}{c}\text { Assessment of Helicobacter } \\
\text { pylori status }\end{array}$} & \multirow[b]{2}{*}{ Description of the main findings } & \multirow[b]{2}{*}{ Reason for exclusion } \\
\hline & & & & Sample & Method & & \\
\hline Kivi et al. $(2005)^{(10)}$ & $\begin{array}{l}\text { Sweden, } \\
\text { Stockholm }\end{array}$ & $\begin{array}{l}\text { 'The present cross- } \\
\text { sectional study in an } \\
\text { extension of a previous } \\
\text { serological survey in } 11 \\
\text { Stockholm schools, } \\
\text { conducted between } \\
\text { February and April } \\
\text { 1998, investigating risk } \\
\text { factors for H. pylori } \\
\text { infection in children' }\end{array}$ & $\begin{array}{l}10-14 \\
12^{*}(\mathrm{ND})\end{array}$ & Blood & ELISA (IgG) & $\begin{array}{l}\text { 'No associations with index child } \\
\text { infection were found for }[\ldots] \\
\text { breastfeeding }[\ldots] \text { ] }\end{array}$ & $\begin{array}{l}\text { An RR or suitable } \\
\text { information to compute it } \\
\text { was not provided }\end{array}$ \\
\hline $\begin{array}{l}\text { Vivatvakin et al. } \\
\qquad(2004)^{(55)}\end{array}$ & $\begin{array}{l}\text { Thailand, } \\
\text { central, } \\
\text { northern, } \\
\text { north-eastern } \\
\text { and eastern }\end{array}$ & $\begin{array}{l}\text { ‘...] sera of Thai children } \\
\text { who visited the Out } \\
\text { Patients Clinics [...] } \\
\text { were collected. [...] } \\
\text { The exclusion criteria } \\
\text { were the children who } \\
\text { had either blood or } \\
\text { plasma transfusion and } \\
\text { history of recurrent } \\
\text { abdominal pain' }\end{array}$ & $\begin{array}{l}0-16 \\
\text { ND (ND) }\end{array}$ & Blood & $\begin{array}{l}\text { ELISA and } \\
\text { Western blot } \\
(\lg G)\end{array}$ & $\begin{array}{l}\text { 'Percentage of breastfeeding in } \\
\text { the population in Korat was } \\
61.25 \% \text {. The selected group of } \\
\text { seropositive children had } 51 \% \\
\text { of exclusive breastfeeding for } \\
\text { more than } 6 \text { months and in only } \\
21.5 \% \text { the seropositive children } \\
\text { had a history of breastfeeding } \\
\text { less than } 6 \text { months' }\end{array}$ & $\begin{array}{l}\text { An RR or suitable } \\
\text { information to compute it } \\
\text { was not provided }\end{array}$ \\
\hline $\begin{array}{l}\text { Glynn et al. } \\
(2002)^{(44)}\end{array}$ & Bolivia, ND & $\begin{array}{l}\text { ‘[..] we conducted a } \\
\text { serosurvey (survey I) to } \\
\text { establish baseline } \\
H . \text { pylori seroprevalence } \\
\text { rates [...]. All children } \\
\text { aged } 6 \text { months through } \\
9 \text { years were eligible to } \\
\text { enroll in the health day } \\
\text { activities, including } \\
\text { testing for } H . \text { pylori [...] } \\
\text { we returned to the } \\
\text { same } 17 \text { villages and } \\
\text { conducted a second } \\
\text { serosurvey (survey II). } \\
{[\ldots] \text { we restricted the }} \\
\text { enrollment in survey II } \\
\text { to children aged } \\
\leq 6 \text { years' }\end{array}$ & $\begin{array}{l}0.5-9 \\
\text { ND (ND) }\end{array}$ & Blood & ELISA (IgG) & $\begin{array}{l}\text { 'Behaviors associated with breast- } \\
\text { feeding, including breast- } \\
\text { feeding from multiple women or } \\
\text { breast-feeding from a woman } \\
\text { who was simultaneously } \\
\text { nursing other children, also } \\
\text { were not significantly } \\
\text { associated with seroconversion' }\end{array}$ & $\begin{array}{l}\text { An RR or suitable } \\
\text { information to compute it } \\
\text { was not provided }\end{array}$ \\
\hline
\end{tabular}




\begin{tabular}{|c|c|c|c|c|c|c|c|}
\hline \multirow{2}{*}{$\begin{array}{l}\text { Authors, year of } \\
\text { publication, } \\
\text { reference }\end{array}$} & \multirow[b]{2}{*}{ Country, region } & \multirow[b]{2}{*}{ Study population } & \multirow{2}{*}{$\begin{array}{l}\text { Age (years): range; } \\
\text { mean (SD) }\end{array}$} & \multicolumn{2}{|c|}{$\begin{array}{c}\text { Assessment of Helicobacter } \\
\text { pylori status }\end{array}$} & \multirow[b]{2}{*}{ Description of the main findings } & \multirow[b]{2}{*}{ Reason for exclusion } \\
\hline & & & & Sample & Method & & \\
\hline $\begin{array}{l}\text { Daugule et al. } \\
\qquad(2001)^{(50)}\end{array}$ & Latvia, Riga & $\begin{array}{l}\text { 'Consecutive children [...] } \\
\text { without symptoms from } \\
\text { the gastrointestinal } \\
\text { tract, who visited their } \\
\text { doctor for a general } \\
\text { checkup or because of } \\
\text { minor health problems' }\end{array}$ & $1-12$ & Expired air & UBT & $\begin{array}{l}\text { 'The univariate associations of } \\
\text { some of the studied risk factors } \\
\text { with } H \text {. pylori positivity are } \\
\text { shown in the table. [...] The } \\
\text { other possible risk factors did } \\
\text { not demonstrate a significant } \\
\text { association with H. pylori } \\
\text { infection' } \\
\text { (Breast-feeding was not included } \\
\text { in the table) }\end{array}$ & $\begin{array}{l}\text { An RR or suitable } \\
\text { information to compute it } \\
\text { was not provided }\end{array}$ \\
\hline $\begin{array}{l}\text { Okuda et al. } \\
\qquad(2001)^{(48)}\end{array}$ & $\begin{array}{l}\text { Japan, } \\
\text { Wakayama }\end{array}$ & $\begin{array}{l}\text { 'This study included } 484 \\
\text { children with no gastric } \\
\text { symptoms, [...] who } \\
\text { were examined at } \\
\text { Wakayama Rosai } \\
\text { Hospital' }\end{array}$ & $0-12$ & Stool & $\begin{array}{l}\text { H. pylori stool } \\
\text { antigen assay }\end{array}$ & $\begin{array}{l}\text { 'The mean period of breast- } \\
\text { feeding of the HpSA positive } \\
\text { group was } 5 \cdot 3 \pm 5.8 \text { months, } \\
\text { while the mean period for the } \\
\text { HpSA negative group was } \\
7.8 \pm 7.4 \text { months }(P=0.02) \text {. } \\
\text { In the } 198 \text { children aged } \\
\text { 1-3-years-old, the mean period } \\
\text { of breast-feeding for the } 14 \\
\text { HpSA positive children was } \\
3.4 \pm 3.5 \text { and for the } 184 \mathrm{HpSA} \\
\text { negative children was } 8.5 \pm 6.9 \\
\text { months }(P=0.003 \text {, Table } 2) \text { ' }\end{array}$ & $\begin{array}{l}\text { It compares the mean } \\
\text { duration of breast- } \\
\text { feeding among } \mathrm{H} \text {. pylori- } \\
\text { infected and non-infected } \\
\text { subjects }\end{array}$ \\
\hline $\begin{array}{l}\text { Rothenbacher et al. } \\
(2000)^{(54)}\end{array}$ & $\begin{array}{l}\text { Germany, Ulm, } \\
\text { Langenau and } \\
\text { Ehingen }\end{array}$ & $\begin{array}{l}\text { 'In this study we included } \\
\text { all infants and children } \\
\text { of Turkish nationality in } \\
\text { whom } 11 \text { participating } \\
\text { pediatricians }[\ldots] \\
\text { conducted a screening } \\
\text { examination' }\end{array}$ & $0-5$ & Stool & $\begin{array}{l}\text { Enzyme } \\
\text { immunoassay }\end{array}$ & $\begin{array}{l}\text { '[...] history of breastfeeding } \\
\text { showed no clear pattern with } \\
\text { prevalence of current infection' }\end{array}$ & $\begin{array}{l}\text { An RR or suitable } \\
\text { information to compute it } \\
\text { was not provided }\end{array}$ \\
\hline $\begin{array}{l}\text { Tindberg et al. } \\
(1999)^{(45)}\end{array}$ & $\begin{array}{l}\text { Sweden, } \\
\text { Stockholm }\end{array}$ & $\begin{array}{l}\text { 'children were recalled for } \\
\text { serology of both } \\
\text { pertussis and } H \text {. pylori } \\
\text { infection and } 201 \text { of } \\
305 \text { identifiable } \\
\text { children accepted. }\end{array}$ & $\begin{array}{l}2,4 \\
\text { ND (ND) }\end{array}$ & Blood & ELISA $(\lg G, \lg A)$ & $\begin{array}{l}\text { 'Length of breastfeeding, i.e. a } \\
\text { mean of } 3 \text { mo for both } \\
\text { seropositive and seronegative } \\
\text { children, could not be correlated } \\
\text { with later } H \text {. pylori infection } \\
\text { status' }\end{array}$ & $\begin{array}{l}\text { An RR or suitable } \\
\text { information to compute it } \\
\text { was not provided }\end{array}$ \\
\hline
\end{tabular}




\begin{tabular}{|c|c|c|c|c|c|c|c|}
\hline \multirow{2}{*}{$\begin{array}{l}\text { Authors, year of } \\
\text { publication, } \\
\text { reference }\end{array}$} & \multirow[b]{2}{*}{ Country, region } & \multirow[b]{2}{*}{ Study population } & \multirow{2}{*}{$\begin{array}{l}\text { Age (years): range; } \\
\text { mean (SD) }\end{array}$} & \multicolumn{2}{|c|}{$\begin{array}{c}\text { Assessment of Helicobacter } \\
\text { pylori status }\end{array}$} & \multirow[b]{2}{*}{ Description of the main findings } & \multirow[b]{2}{*}{ Reason for exclusion } \\
\hline & & & & Sample & Method & & \\
\hline $\begin{array}{l}\text { Mahalanabis et al. } \\
\left(_{(1996)^{(46)}}\right.\end{array}$ & $\begin{array}{l}\text { Bangladesh, } \\
\text { Nandipara }\end{array}$ & $\begin{array}{l}\text { 'The study was carried } \\
\text { out in a periurban } \\
\text { village named } \\
\text { Nandipara [...] settled } \\
\text { by people of low } \\
\text { socioeconomic status } \\
\text { on government land. } \\
\text { [...] Infants and } \\
\text { children over a wide } \\
\text { age range } 1-99 \\
\text { months were studied' }\end{array}$ & $\begin{array}{l}0.08-8.3 \\
\text { ND (ND) }\end{array}$ & Expired air & UBT & $\begin{array}{l}\text { 'The association between lack of } \\
\text { breastfeeding and } H \text {. pylori } \\
\text { infection could not be tested } \\
\text { because infants and children } \\
\text { under } 3 \text { years were nearly all } \\
\text { breastfed. Although an } \\
\text { association (significant at a } 5 \% \\
\text { level) was shown between } \\
\text { breast-feeding and } H \text {. pylori } \\
\text { infection in children over } 5 \text { years } \\
\text { old, the significance of this } \\
\text { finding is tenous and could be } \\
\text { attributed to the effect of } \\
\text { multiple comparison' }\end{array}$ & $\begin{array}{l}\text { The exposure category } \\
\text { was 'presently receiving } \\
\text { some breast milk'. This } \\
\text { exposure was assessed } \\
\text { in groups of subjects with } \\
\text { wide age ranges (1-3 } \\
\text { months, } 4-35 \text { months, } \\
36-59 \text { months, } \\
60-99 \text { months) }\end{array}$ \\
\hline $\begin{array}{l}\text { Thomas et al. } \\
\left(_{(1993)^{(21)}}\right.\end{array}$ & Gambia, ND & $\begin{array}{l}\text { 'We have measured the } \\
\text { potential protective } \\
\text { effect of specific human } \\
\text { milk IgA by studying } \\
12 \text { mothers and their } \\
\text { infants from a Gambian } \\
\text { village in which most } \\
\text { infants are breast-fed } \\
\text { throughout the first } \\
2 \text { years of life' }\end{array}$ & 3-12 months & Expired air & UBT & $\begin{array}{l}\text { 'We found a relation between the } \\
\text { concentration of specific breast } \\
\text { milk IgA and the age of } \\
\text { acquisition of } H \text {. pylori infection. } \\
\text { By ranking mothers according } \\
\text { to the level of anti- } H \text {-pylori IgA } \\
\text { they secreted [...] their children } \\
\text { could be divided into two groups } \\
\text { according to whether or not } H \\
\text { pylori infection was diagnosed } \\
\text { by } 9 \text { months of age } \\
\text { (Kruskal-Wallis test, } P=0.004) \text {. } \\
\text { All } 5 \text { infected children at this age } \\
\text { came from } 5 \text { mothers with the } \\
\text { lowest specific breast milk IgA. } \\
\text { By } 12 \text { months of age, only } 3 \\
\text { children were infection free, } \\
\text { including the children of the two } \\
\text { mothers who produced the } \\
\text { highest specific breast milk IgA } \\
(P=0.04 \text { )' }\end{array}$ & $\begin{array}{l}\text { It related the levels of IgA in } \\
\text { the mothers and the } \\
\text { acquisition of } H \text {. pylori } \\
\text { infection in the first year } \\
\text { of the child }\end{array}$ \\
\hline
\end{tabular}

ND, not defined; RR, relative risk estimate; UBT, urea breath test. ${ }^{*}$ Median age. 
Appendix 2 Main characteristics and results of the studies included in the meta-analysis

\begin{tabular}{|c|c|c|c|c|c|c|c|c|c|c|c|}
\hline \multirow{3}{*}{$\begin{array}{l}\text { Authors, year } \\
\text { of publication, } \\
\text { reference }\end{array}$} & \multirow[b]{3}{*}{ Country, region } & \multirow[b]{3}{*}{ Study population } & \multirow{3}{*}{$\begin{array}{l}\text { Age (years): range; } \\
\text { mean (sD) }\end{array}$} & & & \multirow{3}{*}{$\begin{array}{l}\text { Breast-feeding } \\
\text { prevalence } \\
\text { among the study } \\
\text { subjects }\end{array}$} & \multirow{3}{*}{$\begin{array}{l}\text { Duration of } \\
\text { breast-feeding/other } \\
\text { measures }\end{array}$} & \multicolumn{4}{|c|}{ RR estimates } \\
\hline & & & & \multicolumn{2}{|c|}{$\begin{array}{c}\text { Assessment of } \\
\text { Helicobacter pylori status }\end{array}$} & & & \multirow{2}{*}{$\begin{array}{l}\text { Reference category } \\
\text { used for RR } \\
\text { estimation }\end{array}$} & \multirow{2}{*}{$\begin{array}{l}\text { Category of } \\
\text { exposure used } \\
\text { for RR } \\
\text { estimation }\end{array}$} & \multirow[b]{2}{*}{ RR $(95 \% \mathrm{Cl})$} & \multirow{2}{*}{$\begin{array}{l}\text { Control for } \\
\text { confounding }\end{array}$} \\
\hline & & & & Sample & Method & & & & & & \\
\hline \multirow[t]{3}{*}{$\begin{array}{l}\text { Jafar et al. } \\
\quad(2013)^{(51)}\end{array}$} & \multirow[t]{3}{*}{ Iran, Sanandaj } & \multirow{3}{*}{$\begin{array}{l}\text { 'This cross-sectional study } \\
\text { was based on samples of } \\
\text { 4-month to 15-year-old } \\
\text { children. [...] The lower } \\
\text { age groups were selected } \\
\text { randomly from the healthy } \\
\text { children who referred to } \\
\text { primary healthcare centers } \\
\text { for vaccination and the } \\
\text { older ones were from } \\
12 \text { schools with different } \\
\text { socioeconomic status } \\
\text { across the city' }\end{array}$} & \multirow[t]{3}{*}{$\begin{array}{l}0.3-15 \\
5 \cdot 6(5 \cdot 4)\end{array}$} & \multirow[t]{3}{*}{ Stool } & \multirow{3}{*}{$\begin{array}{l}\text { Enzyme } \\
\text { immune } \\
\text { assay }\end{array}$} & \multirow[t]{3}{*}{$95.5 \%$} & \multirow[t]{3}{*}{ ND } & No breast-feeding & $\begin{array}{l}\text { Breast-feeding } \\
\text { for }<6 \text { months }\end{array}$ & \multirow{3}{*}{$\begin{array}{l}\mathrm{OR}=0.62 \\
(0.10,3.66) \\
\mathrm{OR}=0.66 \\
(0.21,2.06) \\
\mathrm{OR}=0.79 \\
(0.32,1.92)\end{array}$} & No \\
\hline & & & & & & & & No breast-feeding & $\begin{array}{l}\text { Breast-feeding } \\
\text { for } \geq 6 \text { months }\end{array}$ & & No \\
\hline & & & & & & & & $\begin{array}{l}\text { Not breast-fed or } \\
\text { breast-fed for } \\
<6 \text { months }\end{array}$ & $\begin{array}{l}\text { Breast-fed for } \\
\geq 6 \text { months }\end{array}$ & & No \\
\hline $\begin{array}{l}\text { O'Ryan et al. } \\
(2013)^{(53)}\end{array}$ & Chile, Colina & $\begin{array}{l}\text { 'Mother-infant pairs [...] were } \\
\text { enrolled during } 2006 \text { to } \\
2007 \text { in a 2-year cohort } \\
\text { study. [...] Only healthy } \\
\text { 1-month-old infants were } \\
\text { enrolled' }\end{array}$ & $\begin{array}{l}\text { Baseline: birth } \\
\text { Median time of } \\
\text { follow-up: } \\
60 \text { months }\end{array}$ & Stool & ELISA & ND & ND & $\begin{array}{l}\text { Not exclusively } \\
\text { breast-fed at } \\
6 \text { months }\end{array}$ & $\begin{array}{l}\text { Exclusive } \\
\text { breast- } \\
\text { feeding at } \\
6 \text { months }\end{array}$ & $\begin{array}{l}\mathrm{OR}=1.71 \\
(0.66,4.47)\end{array}$ & No \\
\hline $\begin{array}{l}\text { Muhsen et al. } \\
(2012)^{(7)}\end{array}$ & $\begin{array}{l}\text { Israel, Northern } \\
\text { region }\end{array}$ & $\begin{array}{l}\text { 'Mothers of healthy infants } \\
\text { aged } 1 \text { week to } 2 \text { months } \\
\text { [...] were asked to } \\
\text { participate }[\ldots] \text { Mothers of } \\
\text { eligible infants }[\ldots] \text { were } \\
\text { recruited through the local } \\
\text { family health clinics } \\
\text { between January and } \\
\text { August 2007' }\end{array}$ & $\begin{array}{l}1.5 \\
\text { ND (ND) }\end{array}$ & Stool & $\begin{array}{l}\text { Enzyme } \\
\text { immune } \\
\text { assay } \neq\end{array}$ & ND & ND & $\leq 6$ months & $>6$ months & $\begin{array}{l}\mathrm{OR}=0.92 \\
(0 \cdot 40,2 \cdot 11)\end{array}$ & No \\
\hline \multirow[t]{3}{*}{$\begin{array}{l}\text { Ozen et al. } \\
\qquad(2011)^{(34)}\end{array}$} & \multirow[t]{3}{*}{ Turkey, ND } & \multirow{3}{*}{$\begin{array}{l}\text { 'Subjects for the study were } \\
\text { selected from the school } \\
\text { register }[\ldots] \text { '... }\end{array}$} & \multirow[t]{3}{*}{$\begin{array}{l}6-15 ; \\
9.8(2 \cdot 0) \dagger\end{array}$} & \multirow[t]{3}{*}{ Blood } & \multirow[t]{3}{*}{ ELISA } & \multirow[t]{3}{*}{ ND } & \multirow[t]{3}{*}{ ND } & $<4$ months & 4-12 months & \multirow{3}{*}{$\begin{array}{l}\text { OR=1.07 } \\
(0.66,1.74) \| \\
O R=1.00 \\
(0.63,1.59) \| \\
O R=1.03 \\
(0.69,1.55) \|\end{array}$} & \multirow[t]{2}{*}{ No } \\
\hline & & & & & & & & $<4$ months & $>12$ months & & \\
\hline & & & & & & & & $<4$ months & $\geq 4$ months & & No \\
\hline $\begin{array}{l}\text { Miranda et al. } \\
(2010)^{(22)}\end{array}$ & $\begin{array}{c}\text { Brazil, São } \\
\text { Paulo }\end{array}$ & $\begin{array}{l}\text { 'Children and adolescents } \\
\text { were eligible for inclusion if } \\
\text { they were registered at the } \\
\text { outpatient service of } \\
\text { Hospital São Paulo with a } \\
\text { diagnosis of upper airway } \\
\text { infection on week-days. All } \\
\text { eligible individuals were } \\
\text { invited to participate, } \\
\text { without any sampling } \\
\text { procedure' }\end{array}$ & $\begin{array}{l}\text { ND; } \\
6.82(4.07)\end{array}$ & Blood & ELISA (IgG) & $62.2 \%$ & ND & No breast-feeding & $\begin{array}{l}\text { Exclusive } \\
\text { breast- } \\
\text { feeding until } \\
4 \text { months of } \\
\text { age }\end{array}$ & $\begin{array}{l}\mathrm{OR}=0.83 \\
(0.53,1.31)\end{array}$ & No \\
\hline
\end{tabular}


Appendix 2 Continued

\begin{tabular}{|c|c|c|c|c|c|c|c|c|c|c|c|}
\hline \multirow{3}{*}{$\begin{array}{l}\text { Authors, year } \\
\text { of publication, } \\
\text { reference }\end{array}$} & \multirow[b]{3}{*}{ Country, region } & \multirow[b]{3}{*}{ Study population } & \multirow{3}{*}{$\begin{array}{l}\text { Age (years): range; } \\
\text { mean (SD) }\end{array}$} & & & \multirow{3}{*}{$\begin{array}{l}\text { Breast-feeding } \\
\text { prevalence } \\
\text { among the study } \\
\text { subjects }\end{array}$} & \multirow{3}{*}{$\begin{array}{l}\text { Duration of } \\
\text { breast-feeding/other } \\
\text { measures }\end{array}$} & \multicolumn{4}{|c|}{ RR estimates } \\
\hline & & & & \multicolumn{2}{|c|}{$\begin{array}{l}\text { Assessment of } \\
\text { Helicobacter pylori status }\end{array}$} & & & \multirow{2}{*}{$\begin{array}{l}\text { Reference category } \\
\text { used for RR } \\
\text { estimation }\end{array}$} & \multirow{2}{*}{$\begin{array}{l}\text { Category of } \\
\text { exposure used } \\
\text { for RR } \\
\text { estimation }\end{array}$} & \multirow[b]{2}{*}{ RR $(95 \% \mathrm{Cl})$} & \multirow{2}{*}{$\begin{array}{l}\text { Control for } \\
\text { confounding }\end{array}$} \\
\hline & & & & Sample & Method & & & & & & \\
\hline $\begin{array}{l}\text { Sýkora et al. } \\
(2009)^{(23)}\end{array}$ & $\begin{array}{l}\text { Czech } \\
\text { Republic, } \\
\text { West } \\
\text { Bohemia }\end{array}$ & $\begin{array}{l}\text { 'asymptomatic children, }[\ldots] \\
\text { chosen prospectively from } \\
\text { the general population' }\end{array}$ & $\begin{array}{l}0-15 ; \\
\text { ND (ND) }\end{array}$ & Stool & ELISA & $80.9 \%$ & $\begin{array}{l}\text { Among HP- } \\
\text { subjects: } 13.99 \\
\text { (sD 19.55) weeks } \\
\text { Among HP+ } \\
\text { subjects: 8.37 } \\
\text { (sD 12.73) weeks }\end{array}$ & $\begin{array}{l}\text { Never have been } \\
\text { breast-fed }\end{array}$ & $\begin{array}{l}\text { Ever have been } \\
\text { breast-fed }\end{array}$ & $\begin{array}{l}\mathrm{OR}=0.55 \\
(0.36,0.84) \uparrow\end{array}$ & $\begin{array}{l}\text { No (the OR } \\
\text { estimate } \\
\text { remained not } \\
\text { statistically } \\
\text { significant after } \\
\text { age } \\
\text { adjustment) }\end{array}$ \\
\hline $\begin{array}{l}\text { Yucel et al. } \\
\qquad(2009)^{(24)}\end{array}$ & $\begin{array}{l}\text { Turkey, } \\
\text { Northern } \\
\text { region }\end{array}$ & $\begin{array}{l}\text { 'children belonging to }[\ldots . .] \text { the } \\
\text { outpatient clinic of a } \\
\text { university medical center, } \\
\text { and samples were } \\
\text { collected from subjects } \\
\text { who included the children } \\
\text { of academic staff } \\
\text { members. [...] The second } \\
\text { site was a public health } \\
\text { center located in the city } \\
\text { center [...]. The last site } \\
\text { was a public health center } \\
\text { [...]' }\end{array}$ & $\begin{array}{l}2-12 ; \\
6.8(3.0)\end{array}$ & Stool & $\begin{array}{l}\text { Immuno- } \\
\text { chromato- } \\
\text { graphic } \\
\text { assay }\end{array}$ & $\begin{array}{l}\text { Prevalence of } \\
\text { breast- } \\
\text { feeding by } \\
\text { duration: } \\
\text { None: } 6.0 \% \\
0-6 \text { months: } \\
49.1 \% \\
0-12 \text { months: } \\
15.7 \% \\
0-24 \text { months: } \\
23.7 \% \\
0-48 \text { months: } \\
5.5 \%\end{array}$ & $\begin{array}{l}\text { A statistical } \\
\text { correlation was } \\
\text { found between } \\
\text { the duration of } \\
\text { breast-feeding } \\
\text { and } H \text {. pylori } \\
\text { positivity, but it } \\
\text { was not significant } \\
(P=0.02 ; 95 \% \text { Cl } \\
0.517,7.349 ; \\
r=-0.18)\end{array}$ & $\begin{array}{l}\text { Never have been } \\
\text { breast-fed or } \\
\text { breast-fed for less } \\
\text { than } 6 \text { months }\end{array}$ & $\begin{array}{l}\text { Breast-fed for } \\
\text { more than } \\
6 \text { months }\end{array}$ & $\begin{array}{l}\mathrm{OR}=0.24 \\
(0.12,0.48) \|\end{array}$ & No \\
\hline $\begin{array}{l}\text { Rodrigues } \\
\text { et al. } \\
(2007)^{(25)}\end{array}$ & $\begin{array}{l}\text { Brazil, Porto } \\
\text { Velho }\end{array}$ & $\begin{array}{l}\text { 'children }[\ldots] \text { selected from a } \\
\text { private clinic and } \\
\text { outpatient services in } \\
\text { surrounding } \\
\text { neighbourhoods. [...] the } \\
\text { inclusion criteria were: }[\ldots] \\
\text { need of venopunction for } \\
\text { laboratory complementary } \\
\text { exams }[\ldots]^{\prime *}\end{array}$ & $\begin{array}{l}2-13 ; \\
7.7 \text { (ND) }\end{array}$ & Blood & $\begin{array}{l}\text { Enzyme } \\
\text { immune } \\
\text { assay }\end{array}$ & $92.5 \%$ & ND & Never breast-fed & Ever breast-fed & $\begin{array}{l}\mathrm{OR}=4.24 \\
(0.93,19 \cdot 32) \|\end{array}$ & No \\
\hline $\begin{array}{l}\text { Ito et al. } \\
\qquad(2006)^{(26)}\end{array}$ & $\begin{array}{l}\text { Brazil, São } \\
\text { Paulo }\end{array}$ & $\begin{array}{l}\text { 'The subjects of this study } \\
\text { were volunteers with } \\
\text { apparently good health } \\
\text { conditions. The family } \\
\text { units in this study were } \\
\text { defined as husband, wife, } \\
\text { and at least one } \\
\text { nonadopted child aged } \\
\text { between } 0 \text { and } 19 \text { years. } \\
\text { The study required that } \\
\text { both parents were } \\
\text { Japanese or Japanese } \\
\text { descendants whose family } \\
\text { members all lived in the } \\
\text { same household' }\end{array}$ & $\begin{array}{l}\text { 0-19; } \\
\text { ND (ND) }\end{array}$ & Blood & $\begin{array}{l}\text { Anti- } H \text {. pylori } \\
\text { lgG } \\
\text { antibody } \\
\text { test }\end{array}$ & ND & ND & $\begin{array}{l}\text { Breast-fed less } \\
\text { frequent than } \\
6 \text { months }\end{array}$ & $\geq 6$ months & $\begin{array}{l}\mathrm{OR}=1.05 \\
(0.44,2.51)\end{array}$ & $\begin{array}{l}\text { Adjusted: for age } \\
\text { and sex }\end{array}$ \\
\hline
\end{tabular}




\begin{tabular}{|c|c|c|c|c|c|c|c|c|c|c|c|}
\hline $\begin{array}{l}\text { Rowland et al. } \\
(2006)^{(29)}\end{array}$ & $\begin{array}{l}\text { Ireland, Dublin, } \\
\text { Mallow and } \\
\text { Kingscourt }\end{array}$ & $\begin{array}{l}\text { 'Nineteen family doctors were } \\
\text { approached to provide } \\
\text { patients for the study [...] } \\
\text { Parents of eligible children } \\
\text { were invited by letter from } \\
\text { their family doctor to } \\
\text { participate in this study' }\end{array}$ & $\begin{array}{l}\text { Baseline: } \\
2-4 ; \\
2.75(0.6)\end{array}$ & Expired air & UBT & $35 \%$ & $\begin{array}{l}\text { There was no } \\
\text { difference in the } \\
\text { rate or duration of } \\
\text { breast-feeding } \\
\text { between infected } \\
\text { and non-infected } \\
\text { index children }\end{array}$ & Not breast-fed & Breast-fed & $\begin{array}{l}\mathrm{OR}=0.54 \\
(0.26,1.09)\end{array}$ & No \\
\hline $\begin{array}{l}\text { Ndip et al. } \\
\quad(2004)^{(30)}\end{array}$ & $\begin{array}{l}\text { Cameroon, } \\
\text { Buea and } \\
\text { Limbe }\end{array}$ & $\begin{array}{l}\text { 'The study population } \\
\text { consisted of } 176 \\
\text { apparently healthy } \\
\text { children [...]. Eighty eight } \\
\text { children were sampled } \\
\text { from each of the two study } \\
\text { sites' }\end{array}$ & $\begin{array}{l}0-10 ; \\
4.29 \text { (ND) }\end{array}$ & Stool & ELISA & ND & ND & $\begin{array}{r}\text { Breast-fed for } \\
\leq 2 \text { months }\end{array}$ & $\begin{array}{r}\text { Breast-fed for } \\
\geq 6 \text { months }\end{array}$ & $\begin{array}{l}\mathrm{OR}=0.20 \\
(0.08,0.49) \|\end{array}$ & No \\
\hline
\end{tabular}




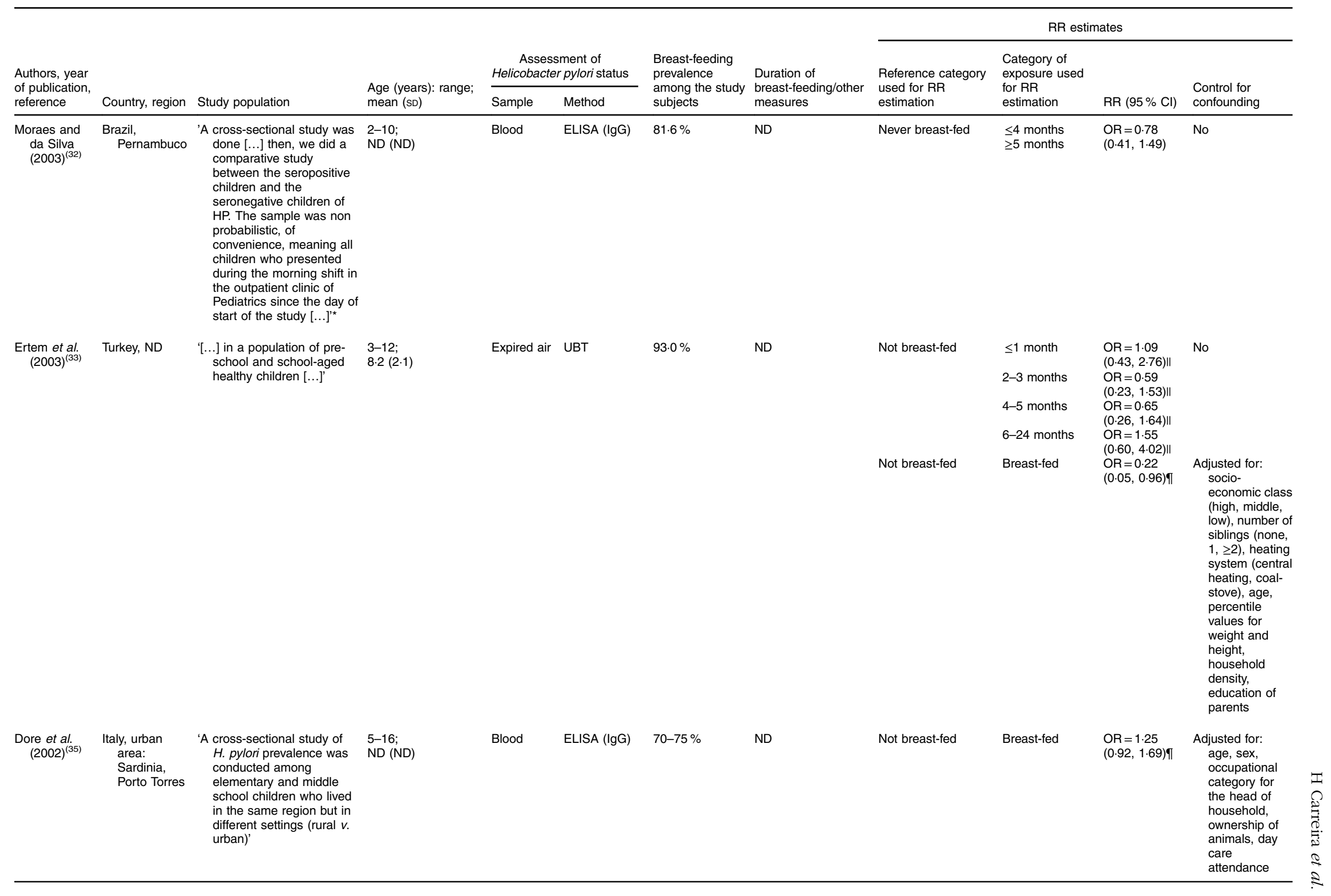


Appendix 2 Continued

\begin{tabular}{|c|c|c|c|c|c|c|c|c|c|c|c|}
\hline \multirow{3}{*}{$\begin{array}{l}\text { Authors, year } \\
\text { of publication, } \\
\text { reference }\end{array}$} & \multirow[b]{3}{*}{ Country, region } & \multirow[b]{3}{*}{ Study population } & \multirow{3}{*}{$\begin{array}{l}\text { Age (years): range; } \\
\text { mean (sD) }\end{array}$} & & & \multirow{3}{*}{$\begin{array}{l}\text { Breast-feeding } \\
\text { prevalence } \\
\text { among the study } \\
\text { subjects }\end{array}$} & \multirow{3}{*}{$\begin{array}{l}\text { Duration of } \\
\text { breast-feeding/other } \\
\text { measures }\end{array}$} & \multicolumn{4}{|c|}{ RR estimates } \\
\hline & & & & \multicolumn{2}{|c|}{$\begin{array}{c}\text { Assessment of } \\
\text { Helicobacter pylori status }\end{array}$} & & & \multirow{2}{*}{$\begin{array}{l}\text { Reference category } \\
\text { used for RR } \\
\text { estimation }\end{array}$} & \multirow{2}{*}{$\begin{array}{l}\text { Category of } \\
\text { exposure used } \\
\text { for RR } \\
\text { estimation }\end{array}$} & \multirow[b]{2}{*}{$\mathrm{RR}(95 \% \mathrm{Cl})$} & \multirow{2}{*}{$\begin{array}{l}\text { Control for } \\
\text { confounding }\end{array}$} \\
\hline & & & & Sample & Method & & & & & & \\
\hline $\begin{array}{l}\text { Malaty et al. } \\
\qquad(2001)^{(11)}\end{array}$ & USA, Houston & $\begin{array}{l}\text { 'The study involved } 13 \\
\text { licensed day care centers } \\
\text { from different locations in } \\
\text { Houston. [...] Children } 15 \\
\text { years old attended day } \\
\text { care centers in the late } \\
\text { afternoon, after regular } \\
\text { school hours, and in the } \\
\text { morning before school. } \\
\text { [...] The sampling of the } \\
\text { study was not random but } \\
\text { depended on invitation } \\
\text { and eligibility as } \\
\text { determined by the entry } \\
\text { criteria' }\end{array}$ & $\begin{array}{l}2-16 ; \\
\text { ND (ND) }\end{array}$ & Expired air & UBT & $62.9 \%$ & ND & Not breast-fed & Breast-fed & $\begin{array}{l}\mathrm{OR}=0.33 \\
(0.17,0.66) \uparrow\end{array}$ & Adjusted for: age \\
\hline \multirow[t]{2}{*}{$\begin{array}{l}\text { Omar et al. } \\
(2001)^{(38)}\end{array}$} & \multirow[t]{2}{*}{ Egypt, Cairo } & \multirow{2}{*}{$\begin{array}{l}\text { 'Children attending the } \\
\text { pediatric outpatient clinic } \\
\text { of Damanhour Teaching } \\
\text { Hospital for minor } \\
\text { illnesses during a six } \\
\text { months period' }\end{array}$} & \multirow[t]{2}{*}{$\begin{array}{l}1.5-16 ; \\
6.8(3.7)\end{array}$} & \multirow[t]{2}{*}{ Blood } & \multirow[t]{2}{*}{ ELISA (IgG) } & \multirow[t]{2}{*}{ ND } & \multirow[t]{2}{*}{$\mathrm{ND}$} & Not breast-fed & Breast-fed & \multirow{2}{*}{$\begin{array}{l}\mathrm{OR}=0.48 \\
(0.18,1 \cdot 29) \uparrow \\
\mathrm{OR}=4 \cdot 3 \\
(1.5,125 \cdot 6)\end{array}$} & No \\
\hline & & & & & & & & $\begin{array}{l}\text { Breast-fed for } \\
\geq 12 \text { months }\end{array}$ & $\begin{array}{l}\text { Breast-fed for } \\
<12 \text { months }\end{array}$ & & $\begin{array}{l}\text { Adjusted for: age } \\
\text { and bed } \\
\text { sharing }\end{array}$ \\
\hline $\begin{array}{l}\text { Naficy et al. } \\
(2000)^{(39)}\end{array}$ & $\begin{array}{l}\text { Egypt, Abu } \\
\text { Homos }\end{array}$ & $\begin{array}{l}\text { '[...] a house-to-house } \\
\text { census of the study } \\
\text { population was performed } \\
\text { [...] Following the census, } \\
\text { all children under } 24 \\
\text { months and new births into } \\
\text { the censused housed } \\
\text { were eligible for enrolment } \\
\text { into the cohort' }\end{array}$ & $\begin{array}{l}0.5-2.9 \\
\text { ND (ND) }\end{array}$ & Blood & ELISA (IgG) & ND & ND & Never breast-fed & Ever breast-fed & $\begin{array}{l}\mathrm{OR}=1 \cdot 4 \\
(0.37,5 \cdot 8)\end{array}$ & Adjusted for: age \\
\hline $\begin{array}{l}\text { Lindkvist et al. } \\
(1999)^{(40)}\end{array}$ & $\begin{array}{l}\text { Ethiopia, } 9 \\
\text { highland and } \\
\text { lowland } \\
\text { villages and } \\
\text { the town } \\
\text { Butajira } \\
\text { situated in } \\
\text { the Rift } \\
\text { Valley }\end{array}$ & $\begin{array}{l}\text { 'The children were selected } \\
\text { randomly by computer } \\
\text { from the BRHP database, } \\
\text { and only one sibling from } \\
\text { each family was selected. } \\
(\ldots . .) \text { ' }\end{array}$ & $\begin{array}{l}\text { Baseline: } \\
1.8-4 ; \\
2.9 \text { (ND) } \\
\text { End of 30-month } \\
\quad \text { follow-up: } \\
4.3-6.5 ; \\
5.5 \text { (ND) }\end{array}$ & Blood & $\begin{array}{l}\text { Immunoblot } \\
\text { assay }\end{array}$ & ND & ND & $\begin{array}{l}\text { Exclusive } \\
\text { breast-feeding } \\
<6 \text { months }\end{array}$ & $\begin{array}{l}\text { Exclusive } \\
\text { breast- } \\
\text { feeding } \\
\geq 6 \text { months }\end{array}$ & $\begin{array}{l}\mathrm{RR}=0.91 \\
(0.61,1.34)\end{array}$ & No \\
\hline
\end{tabular}




\begin{tabular}{|c|c|c|c|c|c|c|c|c|c|c|c|}
\hline $\begin{array}{l}\text { McCallion } \\
\text { et al. } \\
(1996)^{(12)}\end{array}$ & Ireland, Belfast & $\begin{array}{l}\text { 'children [...] attending the } \\
\text { Royal Belfast Hospital for } \\
\text { Sick Children for routine } \\
\text { non-gastrointestinal day } \\
\text { surgery' }\end{array}$ & $\begin{array}{l}3-15 ; \\
\text { ND (ND) }\end{array}$ & Blood & ELISA (IgG) & $20.2 \%$ & $\begin{array}{l}\text { There was a } \\
\text { significant } \\
\text { negative } \\
\text { association } \\
\text { between infection } \\
\text { and breast } \\
\text { feeding }\end{array}$ & $\begin{array}{l}\text { Never breast-fed or } \\
\text { breast fed for less } \\
\text { than } 2 \text { weeks }\end{array}$ & $\begin{array}{l}\text { Breast fed for } \\
2 \text { weeks or } \\
\text { longer }\end{array}$ & $\begin{array}{l}\mathrm{OR}=0.52 \\
(0.29,0.96) \|,{ }^{* *} \\
\mathrm{OR}=0.54 \\
(0.28,1.06)\end{array}$ & $\begin{array}{l}\text { No } \\
\text { Adjusted for: age, } \\
\text { social class } \\
\text { and housing } \\
\text { density }\end{array}$ \\
\hline
\end{tabular}




\begin{tabular}{|c|c|c|c|c|c|c|c|c|c|c|c|}
\hline \multirow{3}{*}{$\begin{array}{l}\text { Authors, year } \\
\text { of publication, } \\
\text { reference }\end{array}$} & \multirow[b]{3}{*}{ Country, region } & \multirow[b]{3}{*}{ Study population } & \multirow{3}{*}{$\begin{array}{l}\text { Age (years): range; } \\
\text { mean (sD) }\end{array}$} & & & \multirow{3}{*}{$\begin{array}{l}\text { Breast-feeding } \\
\text { prevalence } \\
\text { among the study } \\
\text { subjects }\end{array}$} & \multirow{3}{*}{$\begin{array}{l}\text { Duration of } \\
\text { breast-feeding/other } \\
\text { measures }\end{array}$} & \multicolumn{4}{|c|}{ RR estimates } \\
\hline & & & & \multicolumn{2}{|c|}{$\begin{array}{c}\text { Assessment of } \\
\text { Helicobacter pylori status }\end{array}$} & & & \multirow{2}{*}{$\begin{array}{l}\text { Reference category } \\
\text { used for RR } \\
\text { estimation }\end{array}$} & \multirow{2}{*}{$\begin{array}{l}\text { Category of } \\
\text { exposure used } \\
\text { for RR } \\
\text { estimation }\end{array}$} & \multirow[b]{2}{*}{ RR (95\% Cl) } & \multirow{2}{*}{$\begin{array}{l}\text { Control for } \\
\text { confounding }\end{array}$} \\
\hline & & & & Sample & Method & & & & & & \\
\hline $\begin{array}{l}\text { Klein et al. } \\
\quad(1991)^{(52)}\end{array}$ & $\begin{array}{l}\text { Peru, San Juan } \\
\text { de Miraflores }\end{array}$ & $\begin{array}{l}\text { '266 children from families of } \\
\text { low socioeconomic status } \\
\text { (recruited at local health } \\
\text { posts) and } 141 \text { children } \\
\text { from families of high } \\
\text { economic status (recruited } \\
\text { from private schools, } \\
\text { churches, and social } \\
\text { organisations) were } \\
\text { studied. Children from } \\
\text { families of low } \\
\text { socioeconomic status } \\
\text { were regarded as } \\
\text { representative of the } \\
\text { community population on } \\
\text { the basis of family } \\
\text { demographic comparisons } \\
\text { with randomly selected } \\
\text { age-matched children from } \\
\text { the same region' }\end{array}$ & $\begin{array}{l}0.16-12 ; \\
\text { ND (ND) }\end{array}$ & Expired air & UBT & $65.1 \%$ & ND & Not breast-fed & Breast-fed & $\begin{array}{l}\mathrm{OR}=1.25 \\
(0.62,2.52)\end{array}$ & No \\
\hline
\end{tabular}

RR, relative risk; ND, not defined; HP, Helicobacter pylori; UBT, urea breath test.

*Translated from original language to English by the authors of the present review.

tWeighted mean of the mean age of $H$. pylori-positive and -negative subjects.

$¥ H$. pylori infection was defined as having at least two positive tests at examinations obtained at age 6 months or later.

§Only considered $H$. pylori infection when the test was positive after the age of 6 months.

IIEstimates computed from the information presented in the paper.

IStudy providing OR estimates for the comparison of the subjects who were never breast-fed with those who were ever breast-fed. To estimate OR for the comparison of those who were ever breast-fed with those who

were never, we computed the inverse of the OR and the respective $95 \% \mathrm{Cl}$.

${ }^{*}$ OR estimate not considered for meta-analysis. 